軽金属 第64巻 第9号 (2014)，419-432

$$
\text { アルミニウム電解コンデンサ用箔 }
$$

\begin{abstract}
Journal of The Japan Institute of Light Metals, Vol. 64, No. 9 (2014), 419-432
\end{abstract}
(C) 2014 The Japan Institute of Light Metals

\title{
Foils for aluminum electrolytic capacitors
}

\section{Tomoaki YAMANOI*}

Keywords: aluminum foil, electrolytic capacitor

\section{1.はじめに}

コンデンサ（キャパシタ）は，電子回路に不可欠な電子部 品であり, 電気製品, 電子機器の小型化・薄肉化, 高密度化, 高性能・高信頼性に対応すべく，七ラミックコンデンサ，各 種フィルムコンデンサ, アルミニウム電解コンデンサ, タン タル電解コンデンサ等, さまざまな種類のコンデンサが開発 されてきた ${ }^{1}$ 。

このうち 99.9〜99.99\% 純度のアルミ箔（以下アルミニウ ムはアルミと略記）を陽極とするアルミ電解コンデンサは, フィルムコンデンサ, セラミックスコンデンサ等と比較して 高静電容量で高耐電圧のものを比較的安価に製造可能である という特徵を活かし，コンデンサの中でも約 3 割の生産量を 占めている。この電解コンデンサに用いられるアルミ箔は, 後述するように通常, 電気化学的エッチングにより桩面処 理（アルミ䇴に凹凸を付ける表面積の拡大処理）されるため, 電解コンデンサ電極用箔用途に固有の特性が要求される。

この電解コンデンサ電極用のアルミ箔（以下，アルミ電 解コンデンサ用箔と呼ぶ), 特に陽極に用いられる高純度ア ルミ䇴については, 過去から多くの解説記事が書かれてい $3^{2) \sim 7)}$ 。本稿では, 100 年以上の歴史のある ${ }^{8)}$, このアルミ 電解コンデンサが現在もなお電子回路の重要な受動部品とし ての価值を保ち, 性能面で進化を続けている理由についての 考察の一助となることを狙いとして，製品，技術が大きく進 化したトピックスを中心に電極箔である高純度アルミ箔の視 点からの概説を試みる。

\section{2. 電解コンデンサとはどんなものか}

\section{1 アルミ電解コンデンサ用箔の種類と特徵}

図 1 に工業的に用いられるアルミ電解コンデンサの基本構 造の模式図を示す。アルミ電解コンデンサは陽極用アルミ䇴 と陰極用アルミ箔をセパレータと呼ばれる電解液を含浸させ た紙（以下，電解紙と呼ぶ）とともに円筒状に巻いた構造を している。図2は, アルミ電解コンデンサの基本原理を示し たものである。コンデンサの静電容量 $C$ は, 一般に

$$
\begin{aligned}
& C=8.854 \times 10^{-12} \varepsilon_{\mathrm{r}} S / d \\
& \varepsilon_{\mathrm{r}}: \text { 誘電体の誘電率 } \\
& S: \text { 誘電体の表面積 }\left(\mathrm{m}^{2}\right) \\
& d: \text { 誘電体の厚さ }(\mathrm{m})
\end{aligned}
$$

なる式で与えられる。

アルミ電解コンデンサの誘電体はアルミ酸化皮膜 $\left(\mathrm{Al}_{2} \mathrm{O}_{3}\right)$ であり, その $\varepsilon_{\mathrm{r}}$ は 8 10 でほぼ一定の值をとる。また, 誘電 体の厚さ $d$ は使用電圧が高くなるほど厚くする必要があり,

一般的には薄くすることは難しい。そこで, 静電容量の増大 には表面積を大きくする方法が用いられる。

アルミ電解コンデンサは凹凸のあるアルミ箔の表面に形成 される酸化膜とその凹凸に回り达むようにして存在する電解 液を利用することから，箔の表面積の拡大により静電容量を 著しく大きくすることが可能である。このため，後述するよ うに箔をエッチングすることで表面積の拡大が試みられてき た。

図3はアルミ電解コンデンサの製造工程を示したものであ る。アルミ電解コンデンサは, アルミ電極箔, リード線, 電 解紙, 電解液, 封口ゴム, アルミケース, スリーブ（外側の

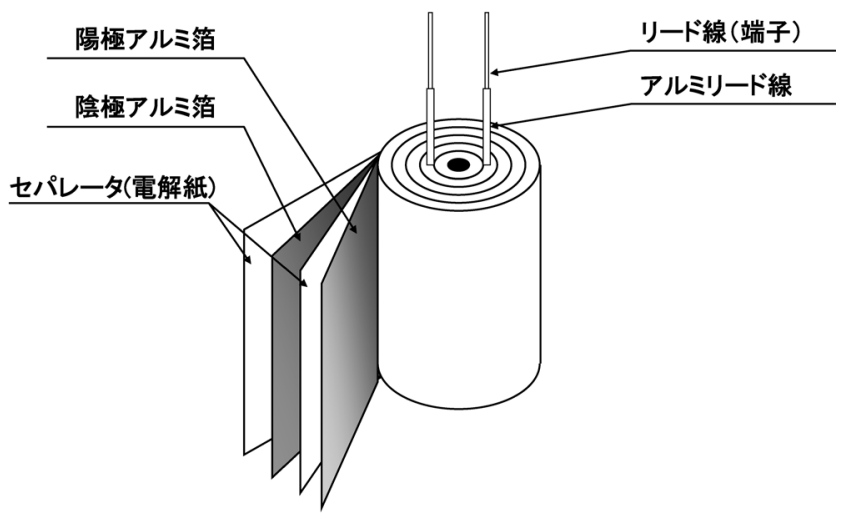

図1 素子の基本構造（模式図）

*昭和電工株式会社 アルミ圧延品事業部（テ590-8576 大阪府堺市堺区海山町 6-224）。Aluminum Rolled Products Division SHOWA DENKO K.K. (6-224 Kaisan-cho, Sakai-ku, Sakai-shi, Osaka 590-8576). E-mail: yamanoi.tomoaki.xhopf@showadenko.com

受付日：平成26年1月21日＼cjkstart受理日：平成26年6月2日 
樹脂カバー）等々，多くの部品で構成されているが，その中 で電極箔となるアルミ箔は，前述した表面積の拡大のための 「粗面化（エッチング）」工程と誘電体皮膜を形成させる「化 成」工程を経て図 1のように巻回 (巻付け) される。これが, 巻回型アルミ電解コンデンサと呼ばれる所以である。

\section{2 なぜ高純度アルミ箔が使われるのか}

アルミ電解コンデンサは，まず使用される電圧によって 定格皮膜耐電圧Vfを選定する必要がある。これに用いられ る箔を大別すると表1のようになる。陽極用に用いられるア

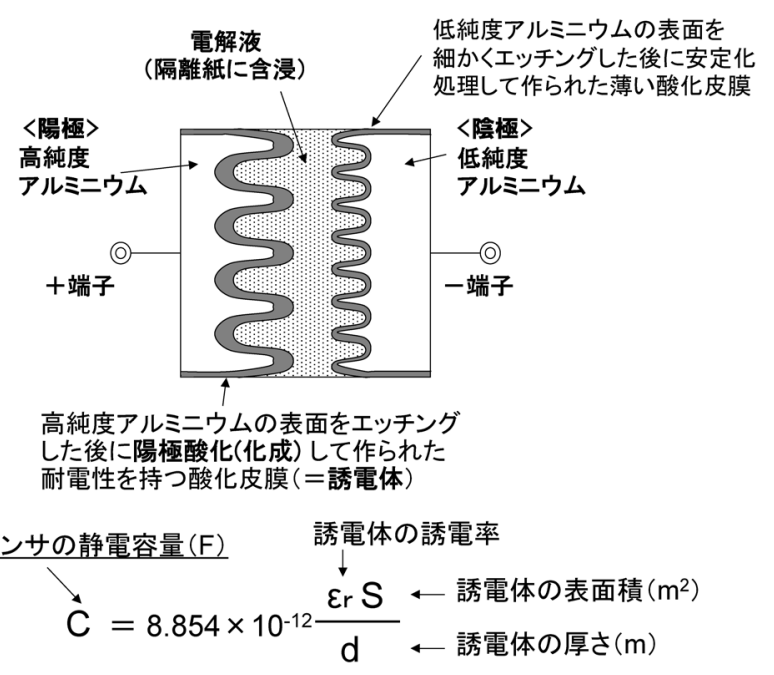

図2アルミ電解コンデンサの原理

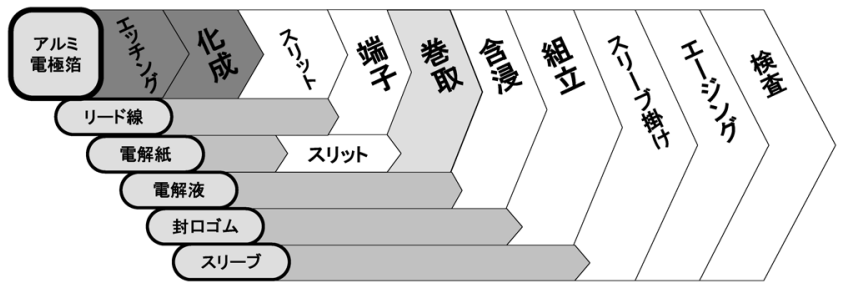

図３ルミ電解コンデンサの製造工程
ルミ箔は高圧用と低圧用に分類される。高圧用アルミ箔に は主として 99.99\%アルミ箔が，低圧用アルミ箔には99.9〜 99.99\%アルミ䇴が使用されており，図2に示したように陽極 箔の表面積 $\mathrm{S}$ の増大のためのエッチング処理と耐電性を持つ 誘電体付与のための化成処理が施される。一方, 陰極箔は動 作原理上，陰極用アルミ箔を陽電位とする高い電圧が加わら ないため, 陽極の持つ静電容量を確保するのに十分な静電 容量を有する薄い酸化皮膜があればよく9， ，エッチング性や 強度・コスト等を重視した 99.4〜 99.8\%程度のアルミ箔や， エッチング性改善のために $\mathrm{Cu}$ を $0.15 \sim 0.30 \%$ 程度含有した合 金箔が使用される。

調質については，陽極箔のうち高圧用アルミ箔は軟質材 が，低圧用アルミ箔は軟質材と硬質材の両方が用いられる。 陰極箔も低圧用アルミ箔と同様，軟質材と硬質材の両方が用 いられている。この調質は, 特に薄箔で高い強度が要求され る陰極箔の一部に硬質箔が優先的に使用される場合を除き, 主に後述するエッチング条件や製造ラインに適合するように 選択されている。

それでは，なぜアルミ電解コンデンサ用箔の中でも特に陽 極箔に高純度アルミ箔が用いられるのであろうか。表 2 に電 解コンデンサに活かされる高純度アルミ箔の材料特性をまと めて示す。電解コンデンサ用電極箔に高純度のアルミ箔が用 いられる理由は大きく次の5つに大別される。

（1）拡面性（エッチング特性）

まず，第 1 に表 1 の箔の断面形態に示されるように，エッ チングという電気化学的な処理によりきわめて大きな表面積 を得ることができることが挙げられる。特に陽極箔では，高 圧用で約 $20 \sim 40$ 倍, 低圧用で約 $80 \sim 100$ 倍の拡面率を有して いる（表2）。

エッチング箔の形態は高圧用に用いられる直流エッチン グによるトンネルエッチング ${ }^{10)}$ と低圧用に用いられる交流 エッチングによるスポンジ状エッチングに大別される。前者 は太いピット径が得られるため, 厚い化成皮膜形成が必要な 高圧用として用いられ，後者は非常に微細なピットが得られ るため低圧用として用いられている。陰極箔も拡面のため,

表 1 アルミ電解コンデンサ用箔の種類とエッチング形態

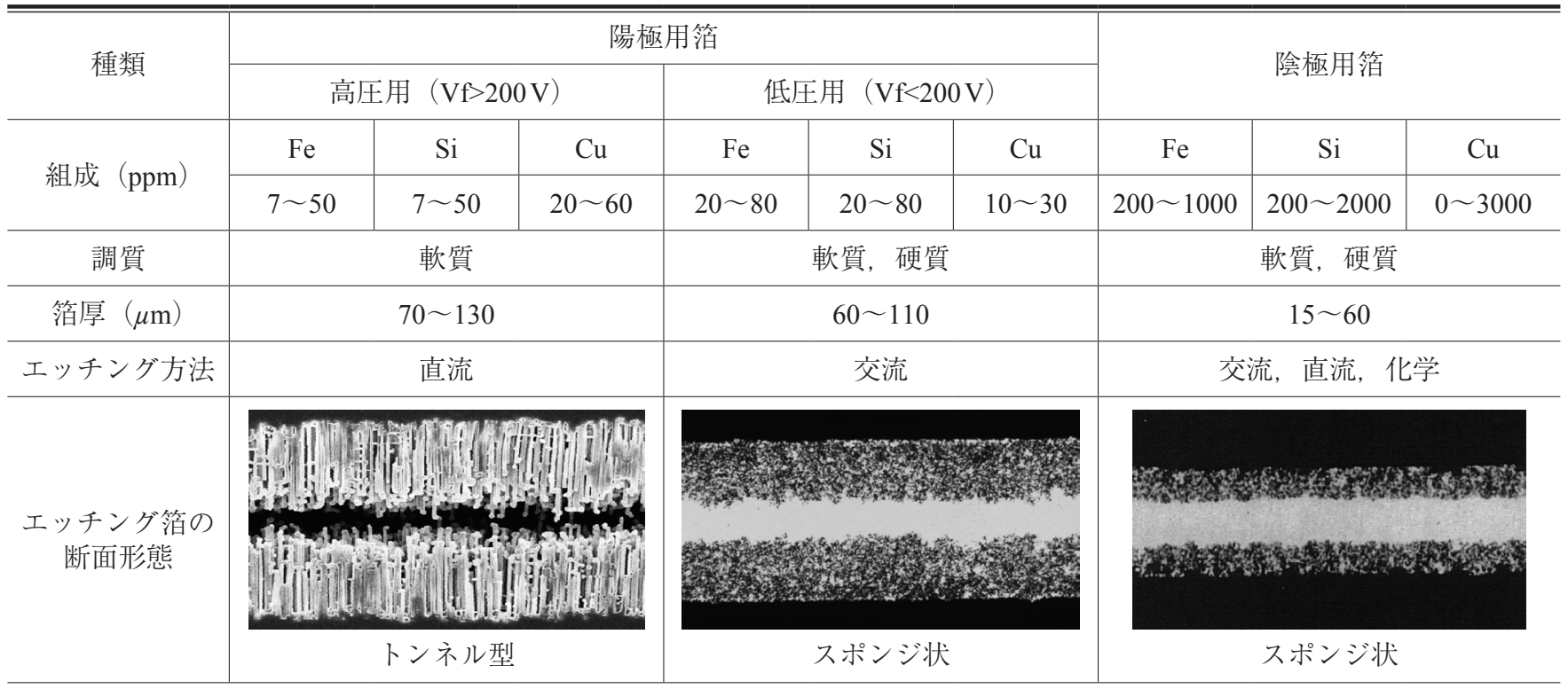


表 2 電解コンデンサに活かされる高純度アルミの材料特性

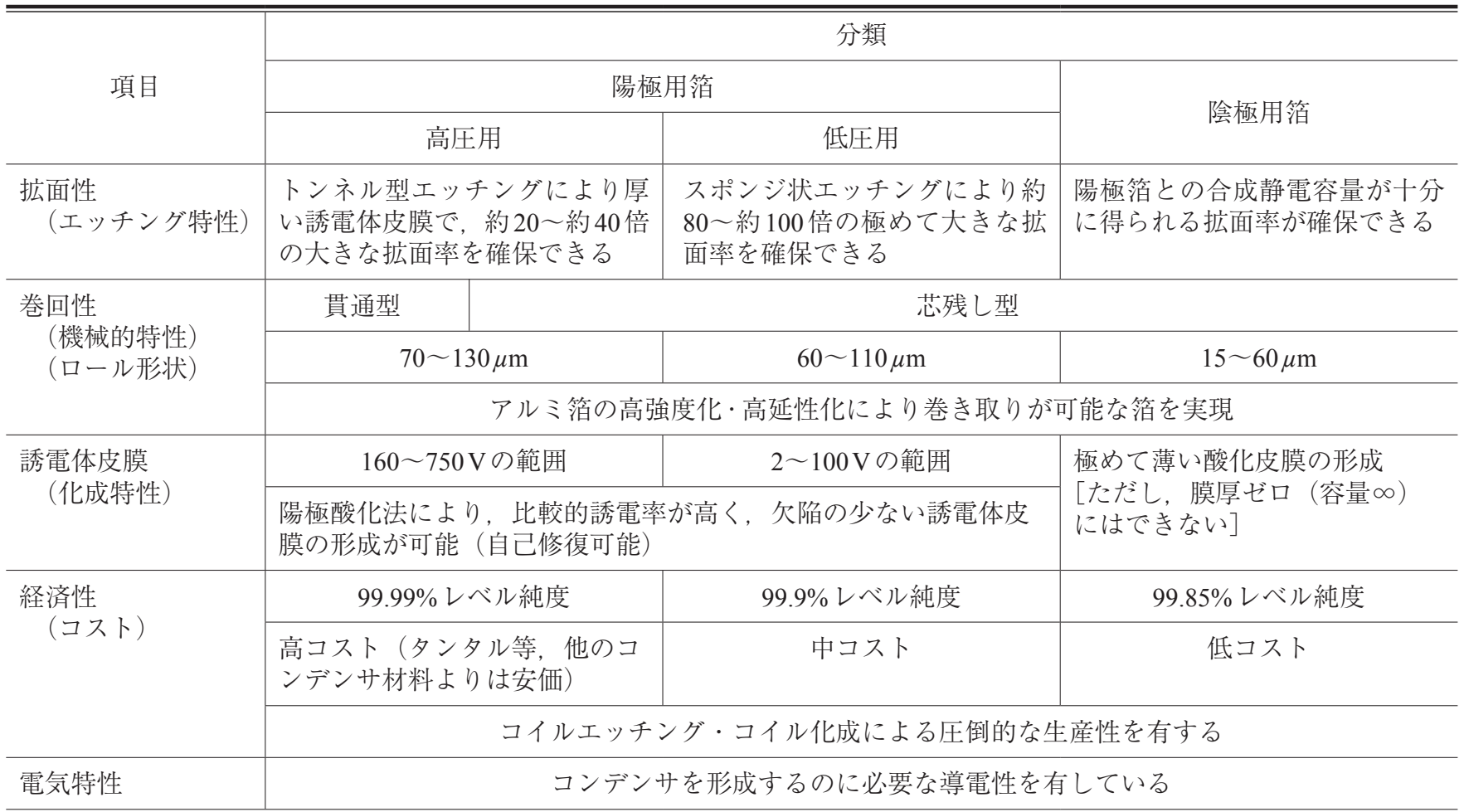

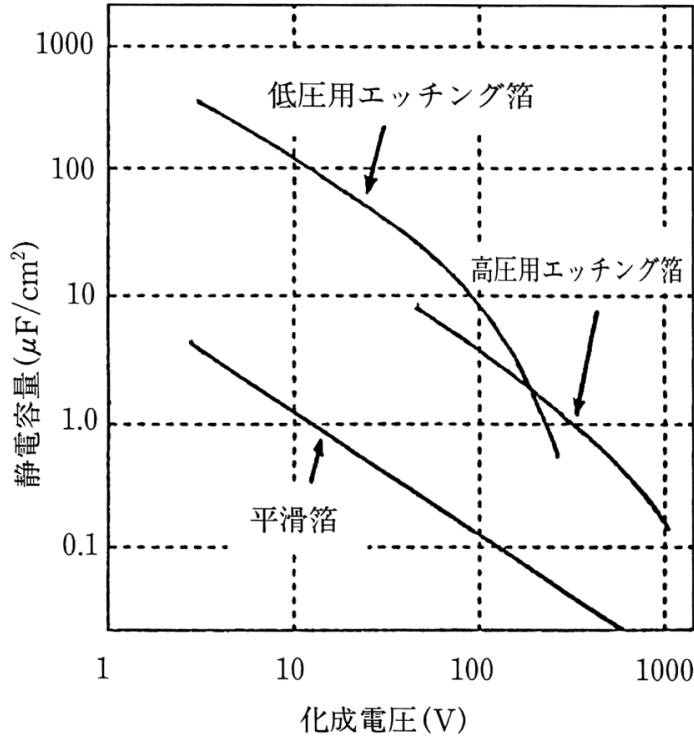

図4 エッチング箔の静電容量-化成電圧特性

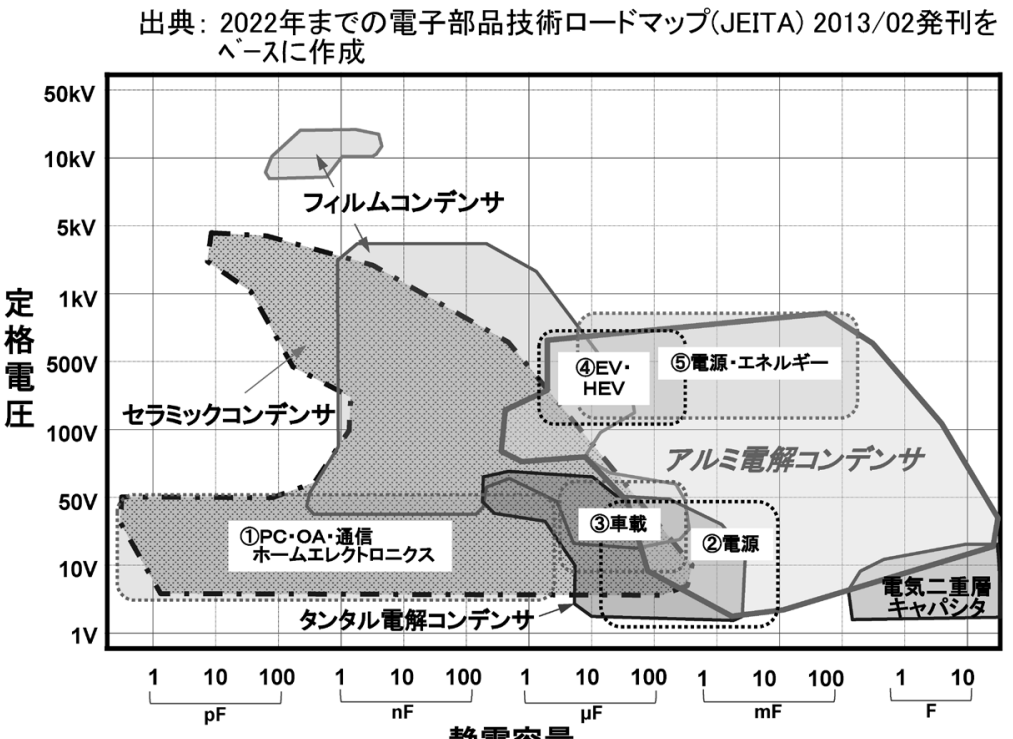

静電容量
通常，スポンジ状エッチングが施される。図4はエッチング 箔の静電容量 $\mathrm{C}$ と化成電圧 $\mathrm{V}$ の関係 $(\mathrm{CV}$ 曲線) を示した例 である ${ }^{11)}$ 。図4 から平滑面に化成処理を施した場合，CV曲 線は負の直線関係になること，エッチングによる拡面処理で 静電容量は大きくなることがわかる。なお，低圧用エッチン グ箔，高圧用エッチング箔それぞれにおいて化成電圧の高い 領域で直線関係が崩れているのは，この領域では化成皮膜が エッチングによる粗面を塞ぎ，有効表面積を減じるためであ る。また，Feに代表されるアルミ中の不純物元素に起因す る溶解減量の増大 ${ }^{12}$ ) ならびに後述するアルミの結晶組織 (集 合組織）は，このエッチングによる拡面処理に大きな影響を 及ぼすことから，陽極箔には高純度ベースのアルミ箔が用い
図5 各種コンデンサの種類とその用途

られている。

（2）巻回性（機械的特性）

図 1 および図 3 に示すようにアルミ電解コンデンサは, そ の製造過程でエッチング，化成，スリット，端子付けといっ た工程を経た後に電解紙と重㸚合せて巻き取られ円筒形状に することで小型化できるという特長がある。この過程で箔が 切断したり端子づけの際に破れたりすると製造できなくな る。したがって，これらの工程で破断しない特性（延性・曲 げ性) が求められる。

（3）誘電体皮膜（化成特性）

図2の原理図を見れば明らかなように,アルミ電解コンデ ンサは陽極側の高純度アルミの表面をエッチングした後に化 
成処理して作られた緻密な陽極酸化皮膜（=誘電体皮膜）が コンデンサとしての電気特性を決めることになる ${ }^{13)}$ 。電気 特性のうち耐電圧や漏れ電流については，陽極酸化皮膜中 に含有されうる不純物元素の影響を強く受け, 特に Feはア ルミとの金属間化合物を形成し，酸化皮膜中に欠陥を生じ

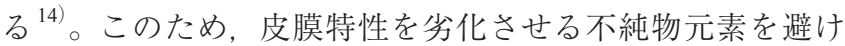
るため高純度ベースのアルミ箔が要求される。

また，アルミ電解コンデンサは，この陽極酸化皮膜に欠陥 があったり，外部要因で新たに欠陥が生じた場合でも，電解 液の酸化作用により皮膜の欠陥をある程度自己修復すること ができる。このことは，アルミ電解コンデンサの信頼性を向 上させる要因の一つとなっている。

（4）経済性（コスト）

現在の高純度アルミ箔は圧延加工，次工程であるエッチン グ工程，化成工程がすべてコイル化されており生産性が著し く向上している。また，後述するようにアルミの精製技術の 進歩とともに供給量, 価格面で競争力のある高純度アルミ箔 が多量に生産可能となっている。

また，高純度アルミを誘電体の材料として見た場合にタン タル酸化物よりも安価であることがタンタル電解コンデンサ より製造コスト面で優位な理由の一つともなっている。

（5）電気特性（導電性）

エッチングされたアルミがそのまま陽極酸化されてコンデ ンサが形成されているため，電極となるアルミと誘電体皮膜 との密着性は極めて高く, 複雑な山凸形状にも電極が追随で きる。また, 高純度アルミは不純物の影響による導電率の低 下が抑えられることも有利な点として挙げられる ${ }^{6), 71} 。$

ただし，アルミ電解コンデンサは極性を持つという制約が
ある。すなわち対極となる電解液とアルミの弁作用によっ て，陽極箔を正極とした場合には直流耐圧を生じるが，陽極 箔を陰極とした場合には低い電圧（1２V）でも電流が流れ

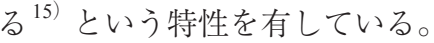

3. コンデンサの中でのアルミ電解コンデンサの位 置づけ

\section{1 コンデンサの種類とその用途}

図5に各種コンデンサがどのような静電容量と定格電圧の 領域でどんな用途に使われているのかを示す ${ }^{16)}$ 。セラミッ クコンデンサは一般に $\mathrm{pF}$ から $\mathrm{nF}$ の領域で使われることが多 く, 特にその小型薄型のメリットを活かして $50 \mathrm{~V}$ 以下の定 格電圧で家電，携帯電話等に使用される例が多い。また，近 年では誘電体層の薄型化・多積層化と誘電体材料の開発によ り大容量化を実現し, $100 \mu \mathrm{F}$ クラスの低圧用素子も出てきて いる。この定格電圧の領域は, 「(1) PC・ OA ・ 通信ホームエ レクトロニクス」をはじめとする信号回路用途や「(2)電源用 途」,「(3)車載用途」に多く使われている。ここは, アルミ電 解コンデンサやタンタル電解コンデンサが得意とする領域 で，これらコンデンサによる競争が激しい。一方，フィルム コンデンサは, ポリエステル, ポリカーボネート, ポリプロ ピレン，ポリスチレンなどを誘電体として用い，絶縁性の高 さと誘電損失（電圧と電流の位相差から生じる電力損失）の 低さから高電圧あるいは高周波用途に用いられている。近 年，難しいとされていたフィルムの薄膜化 $(3 \mu \mathrm{m}$ 以下 $)$ が 可能となり小型高静電容量のものが得られ，「(4) EV ・ HEV」 をはじめとする数百〜千Vクラスの電源用途への展開が拡 がっている。
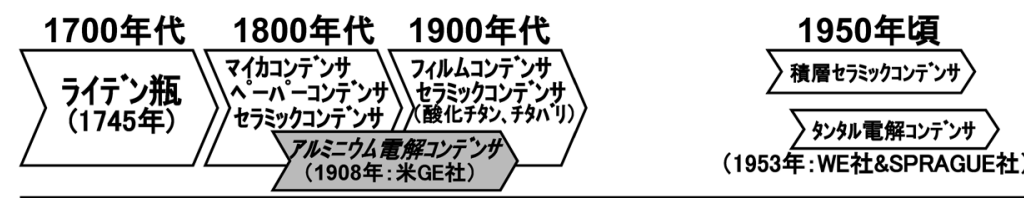

1980年頃

(1953年:WE社\&SPRAGUE社)

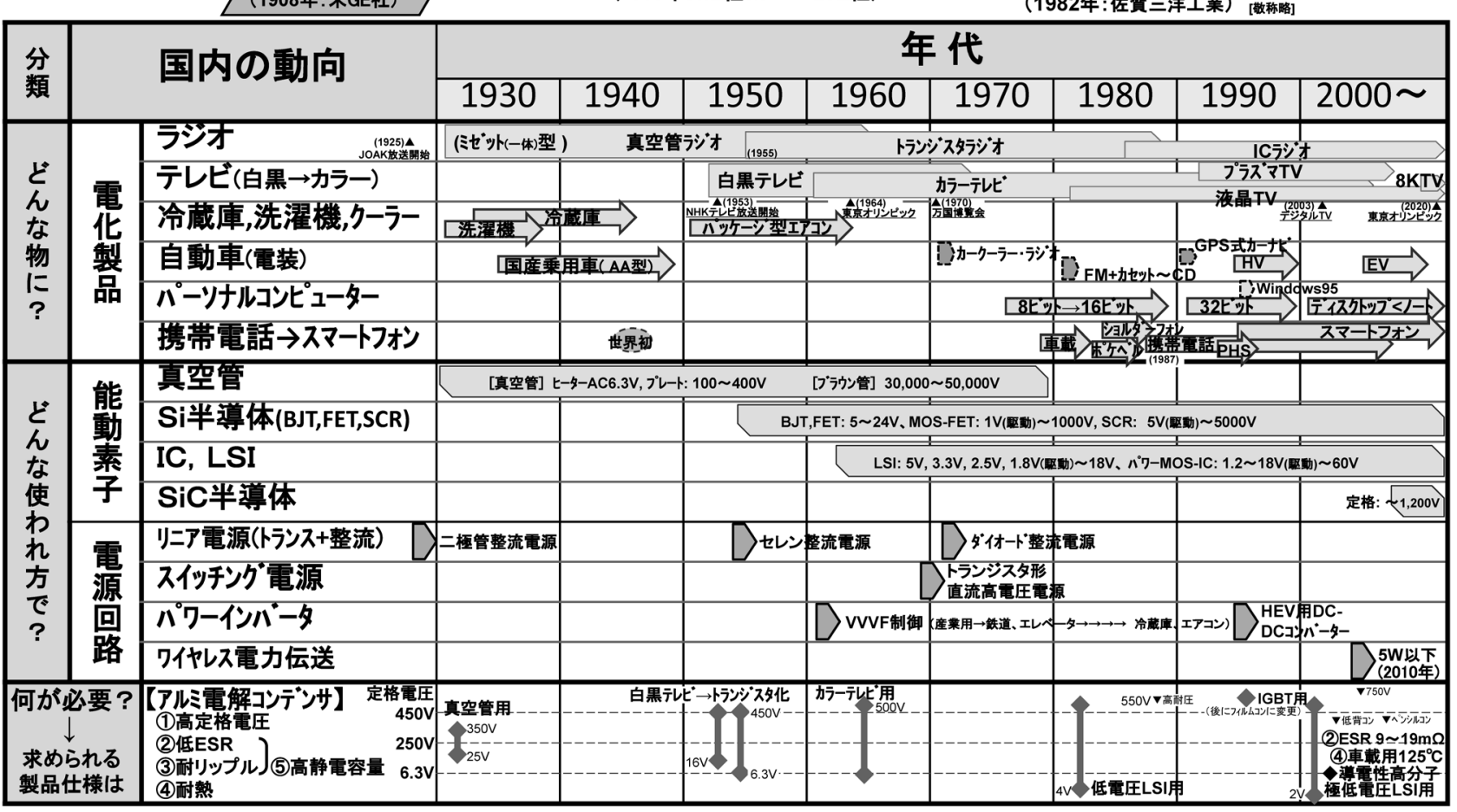

図6 製品とコンデンサの歴史とアルミ電解コンデンサへの要求 
アルミ電解コンデンサは, その誘電体皮膜の厚さを陽極酸 化処理によって幅広く変えられる利点と他のコンデンサには ない拡面処理技術を生かし，低い定格電圧から高い定格電圧 まで小型で安価なコンデンサを提供してきた。しかしながら 上述のような他のコンデンサに一部の領域を奪われつつあ る。そのような中でも低圧の高静電容量側の「(2)電源用途」 や高圧高静電容量側の「(5)電源・エネルギー用途」はアルミ 電解コンデンサに代わるものがない。また導電性高分子アル ミ固体電解コンデンサのようなこれまでアルミ電解コンデン サの課題とされてきたESR（等価直列抵抗：コンデンサの直 流抵抗成分）の低減や長寿命化を達成した素子も開発され, それぞれの境界領域においても競争は続いている。

\section{2 コンデンサの歴史とアルミ電解コンデンサへの要求 の変遷}

図6にアルミ電解コンデンサへの要求が時代とともにどう 変化してきたかを知るために電化製品とそれに使われる素 子，電源回路をコンデンサの歴史と比較した。

真空管が全盛の時代には，低圧側の定格電圧が $25 \mathrm{~V}$, 高圧 側の定格電圧が $250 \sim 350 \mathrm{~V}$ といった比較的狭い使用電圧範 囲であったが，テレビの普及によりブラウン管の駆動回路に 対応すべく高圧側の定格電圧が $450 \mathrm{~V}$ クスにまで引き上げ られた。一方，真空管から半導体への世代交代に伴い，低圧 側の定格電圧が $4 \mathrm{~V}$ ，さらに $2 \mathrm{~V}$ と低くなり，また $\mathrm{PC}$ 電源回 り等の高周波回路，車載用途への適用から低ESR 化，耐リッ プル性（脈流負荷による発熱耐性），耐熱性が求められてき た。それらに対し，アルミ電解コンデンサはそれらの要求特 性を満足すべく，進化を続けている。

\section{4. 高純度アルミと電解コンデンサ用箔への適用}

\section{1 高純度アルミの用途}

表 3 に高純度アルミの主要用途と高純度アルミを使用する 理由を示す ${ }^{17)}$ 。高純度アルミの主要用途としては，本稿の アルミ電解コンデンサ用箔のほかに磁気ディスク用基板材が 挙げられる。磁気ディスク基板に要求される特性としては, （1）非磁性，（2）高速回転に耐える剛性，（3）表面研磨加 工性, (4) 平坦度, (5) スパッ夕後の表面が欠陥がないこと,
（6）軽量，（7）耐熱性，（8）耐食性，などが挙げられ，近年 の記録密度の向上とともに次第に金属間化合物等の表面欠陥 の要因となるものを排除した高純度ベースのアルミ箔が用い られるようになってきている。それ以外にも高純度アルミの 特性を活かしたボンディングワイヤ，スパッタリングター ゲット材，超電導安定化材等に使用されている。

\section{2 高純度アルミの製造方法}

現在，一般に工業的に行われている精製技術は，三層電 解法と偏析法である ${ }^{18)}$ 。また, 超高純度 (99.999\%以上) の アルミ精製方法としてはゾーンメルティング法 ${ }^{19)}$ があるが, 大量生産としては不向きである。以下，アルミ電解コンデン サ箔の原料塊の代表的な製法である, 三層電解法と偏析法の 概略について述べる。

三層電解法精製炉の概略を図 7 に示す ${ }^{20)}$ 。三層電解法は電 解槽の中に三つの層（陽極母合金溶湯，精製電解浴，精製 アルミ）を形成させ，電解精製を行う方法である。陽極母 合金には $\mathrm{Al}-\mathrm{Cu}$ の共晶組成が，電解浴には $\mathrm{Na}, \mathrm{Ba}, \mathrm{Al}, \mathrm{Ca}, \mathrm{Mg}$ のふっ化物または塩化物が用いられている。原料には純度 99.85\%のアルミが使われ，精製アルミ $1 \mathrm{t}$ のたり約 14,000〜 $15,000 \mathrm{kWh}$ の電力が必要となる。三層電解法で得られるアル ミの純度は 99.99 99.999\%である。三層電解法は高いアル ミ純度が得られるが, 偏析法に比べ, 電力消費量が多い ${ }^{19)}$ 。

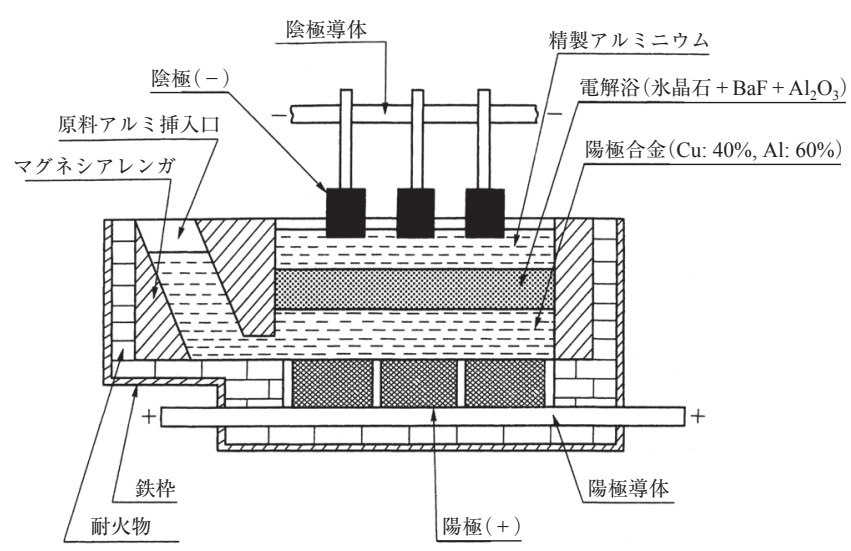

図7 三層電解法の精製炉の構造

表3 高純度アルミニウムの用途

\begin{tabular}{|c|c|c|}
\hline 用途名 & 純度 & 高純度アルミニウムを使用する理由 \\
\hline 電解コンデンサ用箔 & $3 \mathrm{~N}-4 \mathrm{~N}$ & エッチング性，集合組織，誘電体被膜の欠陥少 \\
\hline 磁気ディスク用基板材 & $3 \mathrm{~N}-4 \mathrm{~N}$ & $\begin{array}{l}\text { 基板表面の精度向上，欠陥となる金属間化合物が少ない，表面処理性が } \\
\text { よい, 耐食性 }\end{array}$ \\
\hline 高靶性合金材 & $3 \mathrm{~N}$ & 破壊勒性の向上, 晶出型金属間化合物の数が少なくサイズが小さい \\
\hline 光輝合金 & $3 \mathrm{~N}$ & 表面処理性がよい, 反射率が高い, 耐食性 \\
\hline 真空蒸着材 & $3 \mathrm{~N}$ & 反射率が高い, 光沢等の光学的性質, 耐食性 \\
\hline コンデンサ用リードタブ & $4 \mathrm{~N}$ & 電気伝導性，耐食性 \\
\hline ボンディングワイヤ & $4 \mathrm{~N}$ & 電気伝導性, 耐食性 \\
\hline スパッタリングターゲット材 & $5 \mathrm{~N}$ & $\begin{array}{l}\text { 電気・熱伝導性, } \mathrm{SiO}_{2} \text { との接着性, 耐食性, 半導体メモリのソフトエ } \\
\text { ラー防止のための } \mathrm{U}, \mathrm{Th} \text { 量規制 }\end{array}$ \\
\hline 超伝導安定化材 & $5 \mathrm{~N}$ & RRR值の確保, 低温での電気, 磁気, 熱的性質 \\
\hline
\end{tabular}




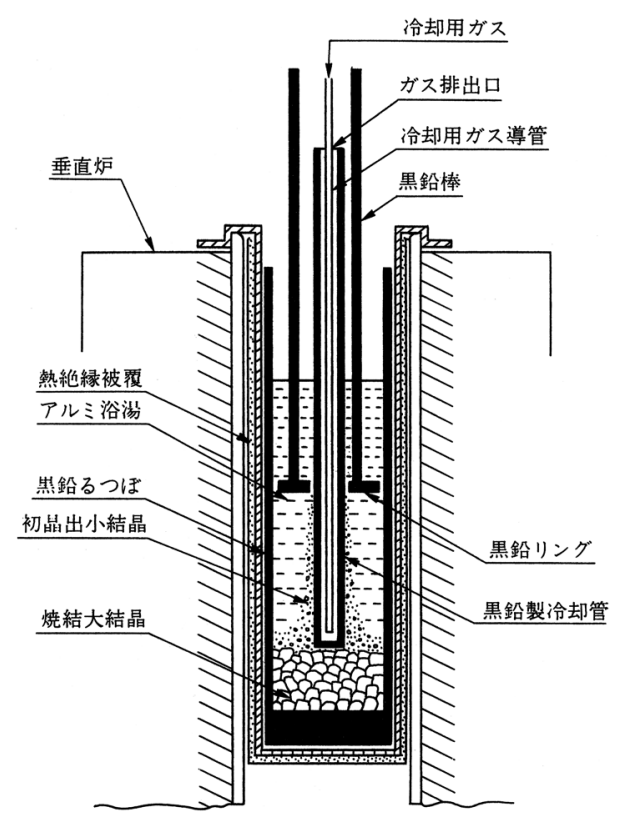

図8 偏析法／分別結晶法（ペシネー法）精製炉の構造

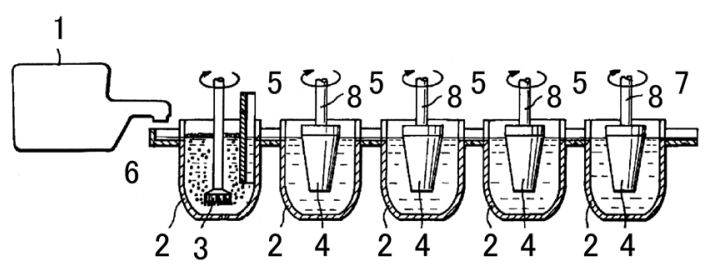

1 溶解炉, 2 るつぼ, 3 攪找機, 4 回転冷却管,

5 導通樋，6 受け樋， 7 排出樋，8 中空回転軸

（a）冷却管凝固法

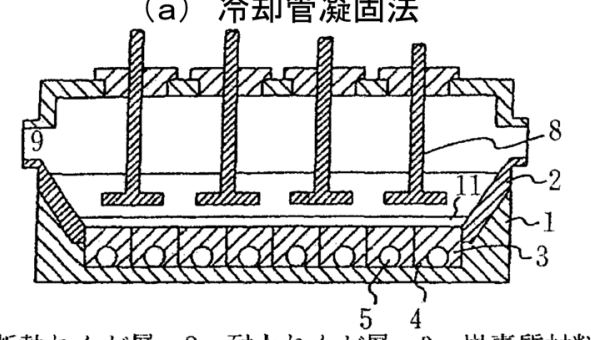

1 断熱れんが層, 2 耐火れんが層, 3 炭素誓材料層,

4 䈐素フロック, 5 泠却媒体流通管, 8 摚汼機,

9 溶融金属導入山, 11 晶出アルミシウム

(b) 底部凝固法

図9 偏析法 /一方向凝固精製炉の構造例

偏析法は晶出した初晶を分別回収する“分別結晶法”と, 冷却凝固界面で成長させる“一方向凝固法”に大別できる。

図8は分別結晶法による精製炉の概略構造の例である ${ }^{21 ） 。 ~}$ 分別結晶法では，まず，融点直上のアルミ溶湯が泠却管に よって冷却されることで冷却管の周りに凝固層ができる。こ の凝固した結晶を掻き落とし， かつ突き固めて圧縮すること で結晶に付着している純度の低いアルミ溶湯が結晶の外部に 排出され，さらに高純度化される。この方法を工業化した例 としては, アルコア法 ${ }^{22)}$, ペシネー法 ${ }^{23)}$, 日軽法 ${ }^{24)}$ がある。

図9に一方向凝固法による精製炉の例を示す。一方向凝固 法はアルミ溶湯の冷却, 凝固を装置のどの部分で行うかによっ てさまざまな方法が考案されているが, 図9(a) は冷却管の 周囲に凝固させる夕イプ, 図9(b) は底部で凝固させる夕 イプである。一方向凝固法として工業化された例としては,

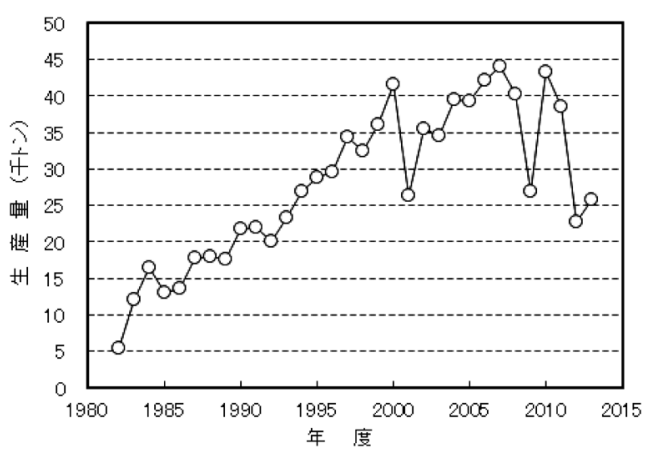

図 10 アルミ電解コンデンサ用箔の生産量の推移 1982１999年：アルミニウム管懇話会より月次で 報告されていたアルミ箔需要部門別特殊分類調査 表の集計による ${ }^{28)}$

2000～2013年：日本アルミニウム協会資料による 推定

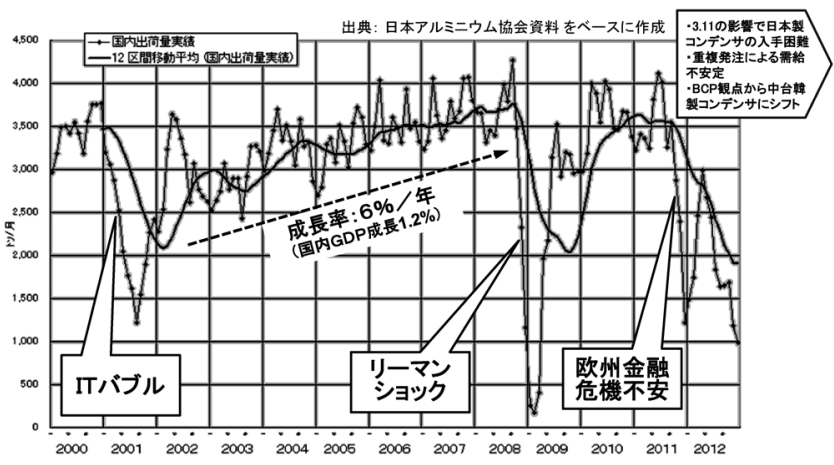

図11 アルミ電解コンデンサ用箔の国内出荷統計

コージュナル法 $(\text { 昭和法 })^{25)}$, 住友法 ${ }^{26)}$, 三菱法 ${ }^{27)}$ がある。

4.3 アルミ電解コンデンサ用箔の製造と技術の変遷

図 10 に 1980 年代から 2013 年にかけてのアルミ電解コンデ ンサ用箔の国内生産量の推移を示す ${ }^{28)}$ 。アルミ電解コンデ ンサ用箔の生産量は 20 年間で約 7 倍となっている。図 11 は, 2000 年以降の電解コンデンサ向けアルミ䇴の国内出荷統計 である ${ }^{29)}$ 。図11 からわかるように, ここ約 10 年は需要に連 動して国内出荷量が大きく変化する傾向にある。2001年の ITバブル後の 2001 年から 2008 年の年平均成長率は約 6\%（同 期間の日本 GDP成長率は $1.2 \%$ ）と一定水準を保っているも のの, その後はリーマンショック・東日本大震災・欧州金融 危機等の影響を相次いで受け，生産量は市況に大きく影響さ れるようになってきている。特に 2011 年の東日本大震災後, 日本製コンデンサの入手が一時困難となり，重複発注による 受注増やその反動による在庫調整等があり，ますます変動予 測が難しくなっている。しかしながら, 直近はその傾向もや や安定し，2012年以降は，再び年率 $10 \%$ を超える回復基調 にある ${ }^{30)}$ 。2014年以降についても年数\%程度の成長が予想 され ${ }^{31}$ ， 車載用途，風力・太陽光発電用途をはじめ，通信・ エネルギー・産業機器分野での需要拡大が見込まれている。

\section{5. アルミ電解コンデンサ用箔の要求特性に及ぼす 材料要因}

5.1 アルミ電解コンデンサ用箔の製造工程

アルミ電解コンデンサは, 図6に示した国内の電化製品の 
旺盛な需要に支えられ，日本を中心として発展してきた。そ の理由の一つとして, アルミ電解コンデンサの国内生産の黎 明期に図 3 に示したアルミ電極箔，エッチング箔，化成箔， 電解紙 ${ }^{32)}$ ，電解液 ${ }^{33)}$ 等のアルミ電解コンデンサの独自部材 の製造メーカーが国内にて製造を開始し，共に成長してきた ことが挙げられる。このうちアルミ電極箔の製造技術の変遷 を考察するための一助とすべく, 図 12 にアルミ電解コンデ ンサ用の陽極箔（低圧，高圧用）ならびに院極用箔の代表的 な製造工程の概略を，図13に国内各社高純度アルミ製錬・ 精製とアルミ電解コンデンサ用箔製造メーカーの操業時期を 示す。図 12 より, 製造工程は大きく分けて, (1)ボーキサイト,
アルミナからアルミを抽出する「製錬」, (2)アルミから不純 物元素を取り除く「精製」, (3)高純度アルミから箔を製造す る「箔地製造」〜䇴製造」の3つに分類される。

図13より，製錬分野は1930年代から順次国内で操業が開 始されたものの1980年代には相次いで撤退している。これ には，1971年の円高，1973年，1979年と相次ぐオイルショッ クによる電力コストの高騰と需要の低迷, 国際市況の低迷, 貿易自由化等による製錬事業の国際競争力の低下が大きく影 響している ${ }^{34)}$ 。これ以降アルミ製錬品は, 海外からの輸入 に大きく依存することとなった。

一方, 精製分野は電力消費量の多い三層電解が比較的早い

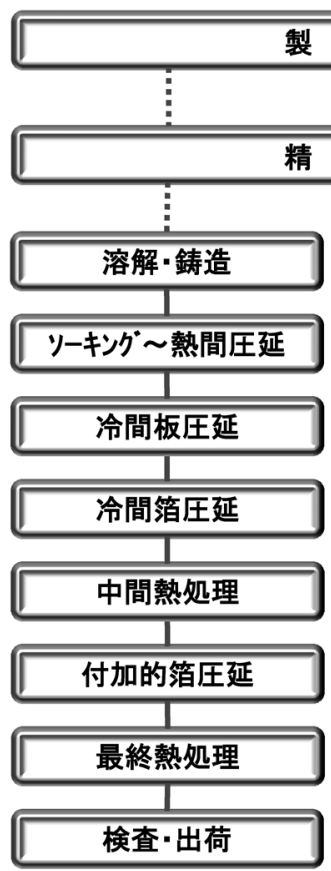

(a)高圧用箔

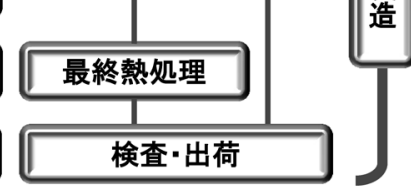

(b)低圧·陰極用箔

図12 代表的な製造工程

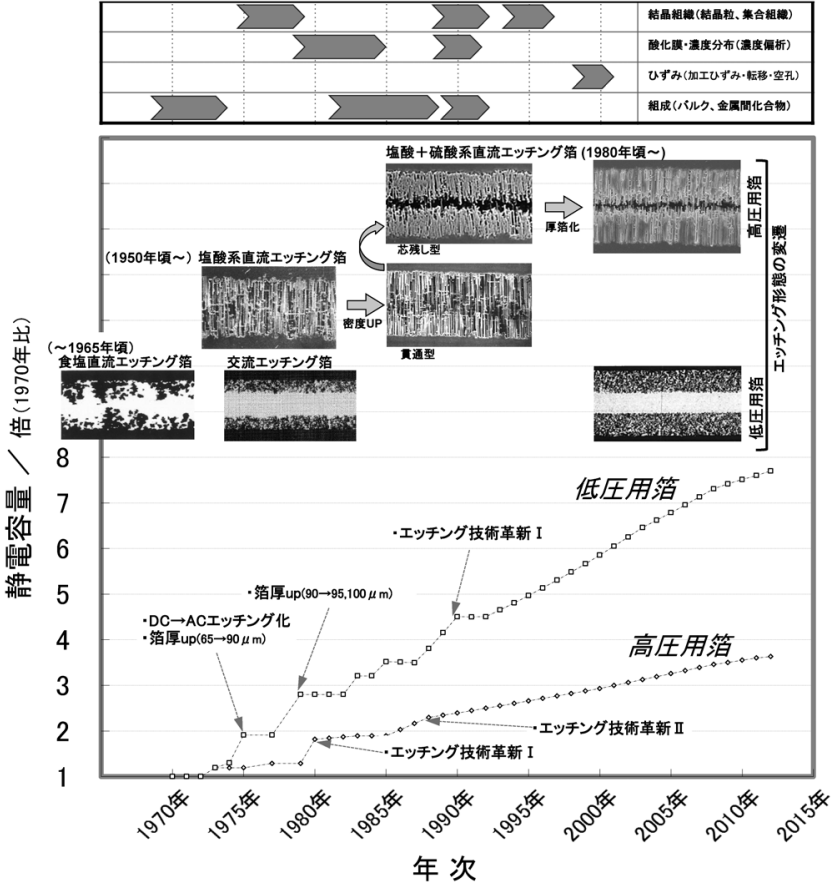

図 14 アルミ電解コンデンサ用箔の静電容量と技術の 変遷

\begin{tabular}{|c|c|c|c|c|c|c|c|c|c|c|}
\hline \multirow{2}{*}{\begin{tabular}{|l|} 
分 \\
野
\end{tabular}} & & \multirow{2}{*}{ メ一カ一 (散称略) } & \multicolumn{8}{|c|}{ 年 代 } \\
\hline & & & 1930 & 1940 & 1950 & 1960 & 1970 & 1980 & 1990 & $2000 \sim$ \\
\hline \multirow{6}{*}{$\begin{array}{l}\text { 製 } \\
\text { 鍊 }\end{array}$} & 木 & 住友化学 & 参人 $\rightarrow$ & $\rightarrow$ & $\rightarrow$ & $\rightarrow$ & $\rightarrow$ & 撤退 & - & - \\
\hline & il & 昭和電工 & 参入 $\rightarrow$ & $\rightarrow$ & $\rightarrow$ & $\rightarrow$ & $\rightarrow$ & 撤退 & - & - \\
\hline & ル & 日本軽金属 & & 参入 $\rightarrow$ & $\rightarrow$ & $\rightarrow$ & $\rightarrow$ & $\rightarrow$ & $\rightarrow$ & $\rightarrow$ \\
\hline & 立 & 三菱化成 & & & 参入 $\rightarrow$ & $\rightarrow$ & $\rightarrow$ & 撤退 & - & - \\
\hline & ル & 三井アルミニウム工業 & & & & & 参入 $\rightarrow$ & 撤退 & - & - \\
\hline & 1 & 住軽アルミニウム工業 & & & & & 参入 $\rightarrow$ & 撤退 & - & - \\
\hline \multirow{7}{*}{$\begin{array}{l}\text { 精 } \\
\text { 製 }\end{array}$} & 三 & 住友化学 & & 参入 $\rightarrow$ & $\rightarrow$ & $\rightarrow$ & $\rightarrow$ & $\rightarrow$ & $\rightarrow$ & $\rightarrow$ \\
\hline & 層 & 日本軽金属 & & & 参入 $\rightarrow$ & $\rightarrow$ & $\rightarrow$ & $\rightarrow$ & 撤退 & - \\
\hline & \multirow{5}{*}{$\begin{array}{l}\text { 偏 } \\
\text { 析 }\end{array}$} & 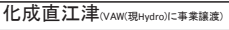 & & & & & & 参入 $\rightarrow$ & $\rightarrow$ & 撤退 \\
\hline & & 昭和電工 & & & & & & 参入 $\rightarrow$ & $\rightarrow$ & $\rightarrow$ \\
\hline & & 住友化学 & & & & & & 参入 $\rightarrow$ & $\rightarrow$ & $\rightarrow$ \\
\hline & & 九州三井アルミニウム工業 & & & & & & 参入 $\rightarrow$ & $\rightarrow$ & $\rightarrow$ \\
\hline & & 日本軽金属 & & & & & & 参入 $\rightarrow$ & $\rightarrow$ & $\rightarrow$ \\
\hline \multirow{7}{*}{\multicolumn{2}{|c|}{$\begin{array}{l}\text { 笼 } \\
\text { 地 } \\
\text { 製 } \\
\text { 造 }\end{array} /$}} & 東洋アルミニウム & 参入 $\rightarrow$ & $\rightarrow$ & $\rightarrow$ & $\rightarrow$ & $\rightarrow$ & $\rightarrow$ & $\rightarrow$ & $\rightarrow$ \\
\hline & & 昭和電工 & & & 参入 $\rightarrow$ & $\rightarrow$ & $\rightarrow$ & $\rightarrow$ & $\rightarrow$ & $\rightarrow$ \\
\hline & & 東海アルミ箔 & & & 参入 $\rightarrow$ & $\rightarrow$ & $\rightarrow$ & $\rightarrow$ & $\rightarrow$ & $\rightarrow$ \\
\hline & & 住軽アルミ箔 注2) & & & & & & 参入 $\rightarrow$ & $\rightarrow$ & $\rightarrow$ \\
\hline & & 三菱アルミニウム & & & & & 参入 $\rightarrow$ & $\rightarrow$ & $\rightarrow$ & $\rightarrow$ \\
\hline & & 日本製箔 注2) & & & & 参入 $\rightarrow$ & $\rightarrow$ & $\rightarrow$ & $\rightarrow$ & $\rightarrow$ \\
\hline & & サン・アルミニウムエ業 注3) & & & & & & 参入 $\rightarrow$ & $\rightarrow$ & $\rightarrow$ \\
\hline
\end{tabular}

図 13 国内各社高純度アルミ製錬・精製とアルミ電解コンデンサ用䇴製造メーカーの操業時期

注 1）䈃地製造メーカー：日本軽金属，昭和電工，古河スカイ・住友軽金属工業（現UACJ），三菱アルミニウム，神戸製鋼所，等。 神戸製鋼所は 2012 年にアルミ簿の製造・販売事業から撤退

注2）2014年1月よりUACJ製簿＼cjkstart注3）2012年10月より東洋アルミ千葉 


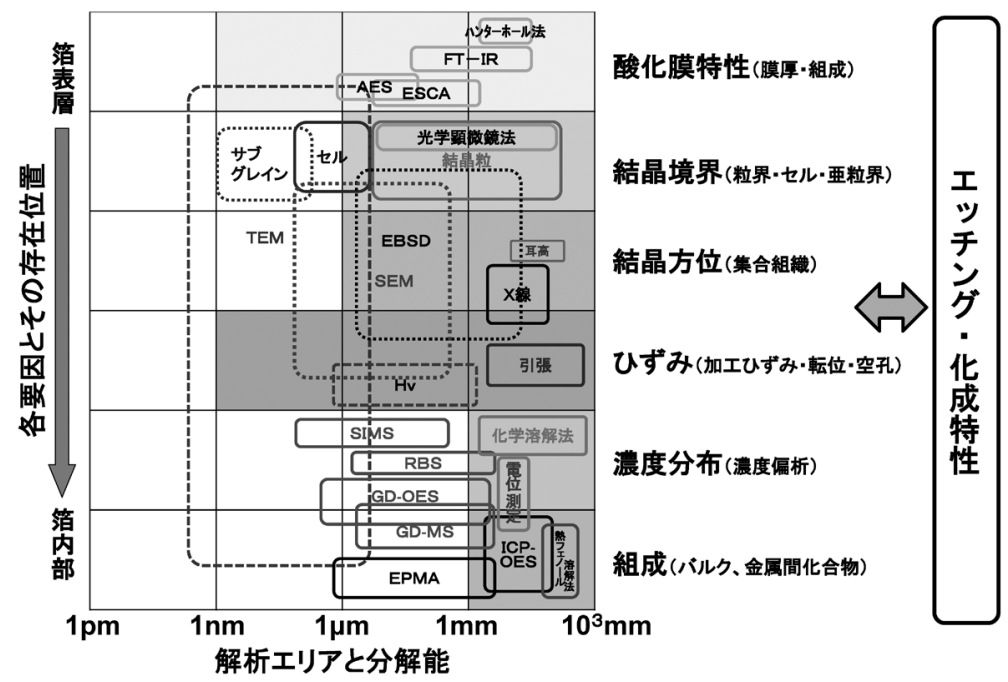

図 15 アルミ電解コンデンサ用箔の組織解析法

段階から導入され，国内生産を開始したが，1980年代にな り，偏析法によるアルミ精製に多くのメーカーが参入してお り，技術革新がこの時期に大きく進んだことがわかる。この ことは，1980年代から 2000 年まで電解コンデンサ用高純度 アルミ箔の生産量が着実な伸びを続けてきた（図 10）こと と無縁ではないと考えられる。

䇴製造は1980年代には現在䇴製造を行っている各社がほ ぼ出そろっている。また，本解説では省略するが，箔製造に ついては, 近年, 特に中国メーカーが台頭しており，高純度 アルミ䇴製造においても国際競争が進んでいる ${ }^{35)}$

\section{2 材料要因と解析手段}

図 14 にアルミ電解コンデンサ用箔のエッチング後の静電 容量と技術の変遷を示す。

静電容量については, 1970年代を 1 とした場合, 2010年ま での 40 年間で高圧用箔は約 3.5 倍, 低圧用箔は約 7.5 倍となっ ている。これにはエッチング技術の進歩とアルミ箔側の技術 の進歩が影響している。エッチング技術変遷の一例として図 14 の中段に断面形状の例を示す。また, 上段にはアルミ箔 側からの材料要因 (結晶組織, 酸化膜 - 濃度分布, 歪, 組成) で顕著な技術が認められた時期を示した。

エッチングについては, 1950年頃からコイル生産設備が 稼働し，生産面での技術革新が進み量産化体制が整ってい る。高圧䇴については，1970年代にエッチング技術（貫通 型エッチング）と結晶組織（立方体方位集合組織）の制御技 術の進歩により，静電容量が大きく向上した。また，1980 年代には貫通型の欠点である折り曲げ強度を改善した芯残し 型と呼ばれるエッチング箔が開発されている ${ }^{36)}$ 。低圧箔に ついては，1970年代に交流エッチング法が確立されること で静電容量が大きく向上し, 現在のスポンジエッチングの基 本技術が完成している ${ }^{36)}$ 。

次に, 図15にアルミ電解コンデンサ用箔の組織解析法と 解析可能な領域を示す。図15の解析手法は, 開発された時 期，あるいは電解コンデンサ用アルミ箔に適用された時期が 各々異なる。例えばSEM（走査型電子顕微鏡）は1970年頃 からエッチング形態の解析に用いられるようになり，材料要 因がエッチングに及ぼす影響を調査するうえで大きな役割を 果たした ${ }^{36)}$ 。また，1980年代になると微量元素の表面濃化

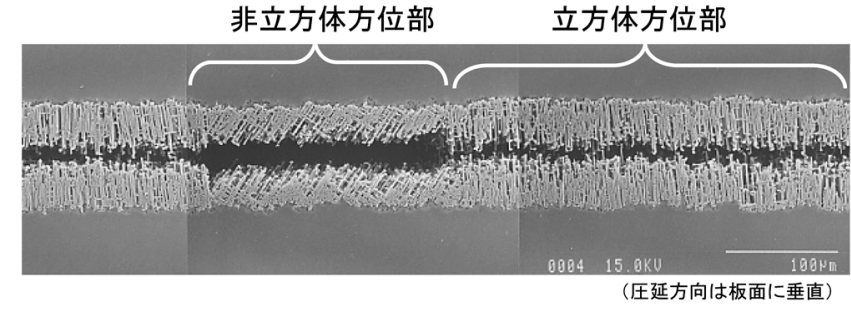

図 16 立方体方位部と非立方体方位部のエッチング写 真 (断面)

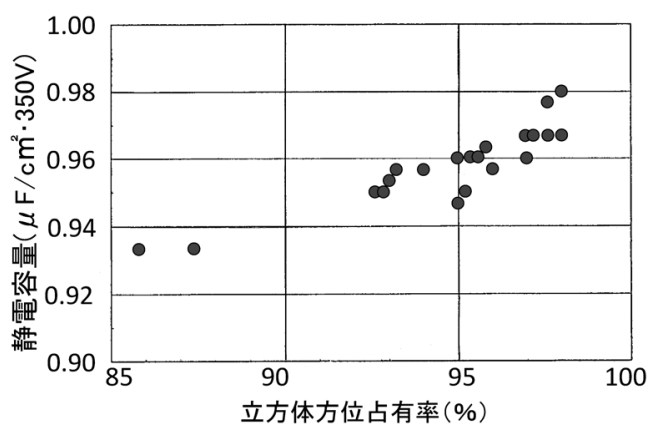

図17 静電容量に及ぼす立方体方位占有率の影響

の解析にSIMS（二次イオン質量分析計）が用いられるよう になり ${ }^{37)}$ ，その後RBS (ラザフォード後方散乱分光法 $)^{38)}$, GD-MS (グロー放電質量分析法 ${ }^{39)}$, GD-OES (グロー放電 発光分析法 $)^{40)}$ ，というそれぞれ異なる特徵を持つ解析手法 が用いられ, 各種元素の表面濃化に対する理解が大いに深 まった。また，トンネル型エッチング用のアルミ箔の特性評 価に欠かせない結晶方位解析についても，古くは箔を浅絞り

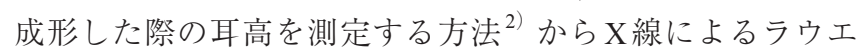
斑点解析 $^{41}$ ～～極点図解析 ${ }^{42)} \sim \mathrm{ODF}$ 解析 ${ }^{43)}$, ECP (エレクト ロンチャネリングパターン法) ${ }^{44)}$ EBSD (電子線後方散乱回 折法 ${ }^{45)}$ と発展するにつれて結晶方位制御のメカニズムが次 第に明らかになってきた。

酸化膜特性の解析については, 古くから酸化膜厚の測定に ハンターホール 法 ${ }^{46)}$ が用いられ, 酸化膜の構造解析の手法 としてFT-IR（フーリ工変換赤外分光光度計 $)^{47)}$ が, 箔表面 


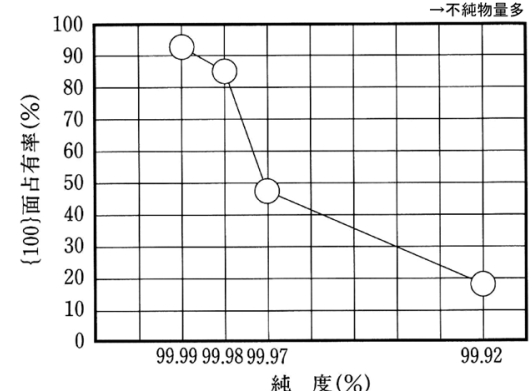

(a) 各純度の馢の立方体方位占有率

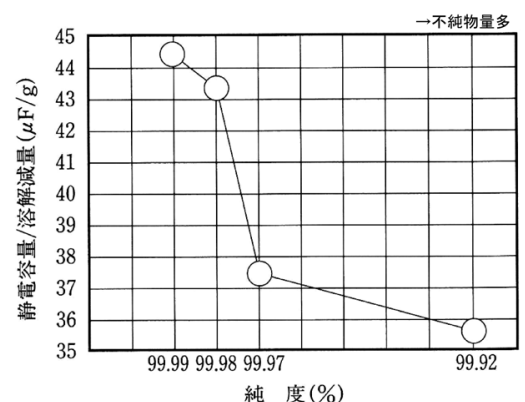

(b) 各純度の箔の静電容量/溶解減量

図18 アルミニウムの純度と材料特性の関係

の電気化学的な特性評価として, 浸漬電位測定や界面イン ピーダンス測定が利用されている ${ }^{48)}$ 。一方, エッチング特 性側の基礎検討として, 直流エッチング条件の検討 ${ }^{49)}$ ５2), 交流エッチング条件の検討 ${ }^{53)}$, 54) も積極的に行われてきた。

このようにアルミ電解コンデンサ用箔は解析技術の進化と ともに発展してきたと言える。以下に, 図 15 の要因別に上 述の解析手法を用いて調査したアルミ箔の材料特性とその エッチング特性への影響を示す。

\section{3 エッチング特性に影響を及ぼす材料特性 \\ 5.3. 1 結晶方位の影響}

図 16 に箔面に立方体方位を有する面（\{100\}面）とそれ以 外の面方位を有する領域の直流エッチング形態の違いを示 す。図16の中央部が非立方体方位部, その両側が立方体方 位の結晶粒である。非立方体方位部のエッチピットの長さは 短く，かつ表面溶解の程度は大きい。エッチング後の箔厚は 立方体方位部より薄くなっている。図17に立方体方位占有 率と直流エッチング後の静電容量との関係を示す ${ }^{55)}$ 。図 17 より, 立方体方位占有率が高いほど静電容量は大きくなる傾 向にあることがわかる。

図18に純度（主に $\mathrm{Fe}, \mathrm{Si}$ 量）の異なる箔について直流エッ チング後の静電容量を測定した結果を示す ${ }^{56)}$ 。純度が高く なるにつれて立方体方位占有率, 静電容量ともに増加してお り，両者に正の相関性のあることが示唆される。

高圧電解コンデンサ用アルミ筞の立方体方位制御につい ては, “部分焼なまし(中間熱処理) +付加的圧延”という 工程で $3 \mathrm{~N}-\mathrm{Al}$ (純度 $99.9 \%$ ）レベルの箔では得られなかっ た立方体方位を得ることができることが1970年頃に明らか になっており ${ }^{57)}$ ，工業的には基本技術が 1975～1980年に確 立されている。その具体的な条件や発生機構についての研

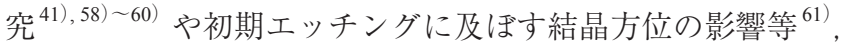
多くの研究が進められてきて，次第にそのメカニズムが解明 されていった。一方，1982１986年にかけて，国内各社が 相次いで偏析技術の導入を進めており（図 13），この結晶方 位制御技術は直ちに安価な偏析塊を用いた箔に適用されて いった。

図19は，EBSDによって箔製造の途中工程である中間熱処 理工程（図 12）での部分焼なまし材とその後の付加的圧延 材の結晶方位粒をマップ化したものである ${ }^{45)}$ 。図中測定点 間の方位差が 1 ～ 15 ○尘さいものを細線で示している。（a） 中間熱処理材には，粒内に細線がなくひずみがほとんどない 再結晶粒と細線がある冷間圧延組織とが混在している。この 細線のない結晶粒に着眼すると, 最終熱処理時に立方体方位
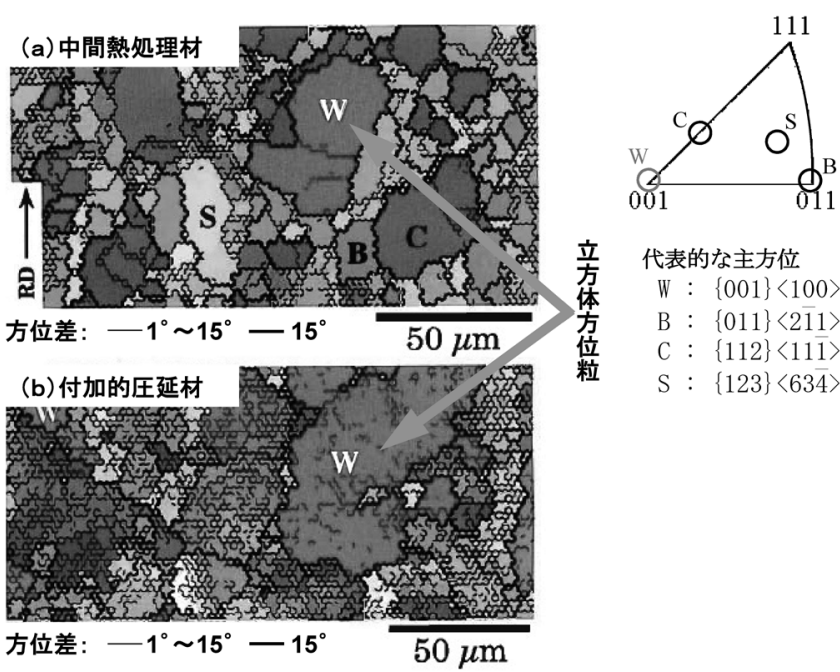

代表的な主方位 W : $\{001\}\langle 100\rangle$ B : $\{011\}\langle 21 \overline{1}\rangle$ C : $\{112\}\langle 11 \overline{1}\rangle$ $\mathrm{S}:\{123\}\langle 63 \overline{4}\rangle$

図19 EBSDによる結晶方位マップ

$8 \mathrm{ppm} \mathrm{Si}-8$ ppm Fe-50 ppm Cu, 箔厚 : $110 \mu \mathrm{m}$

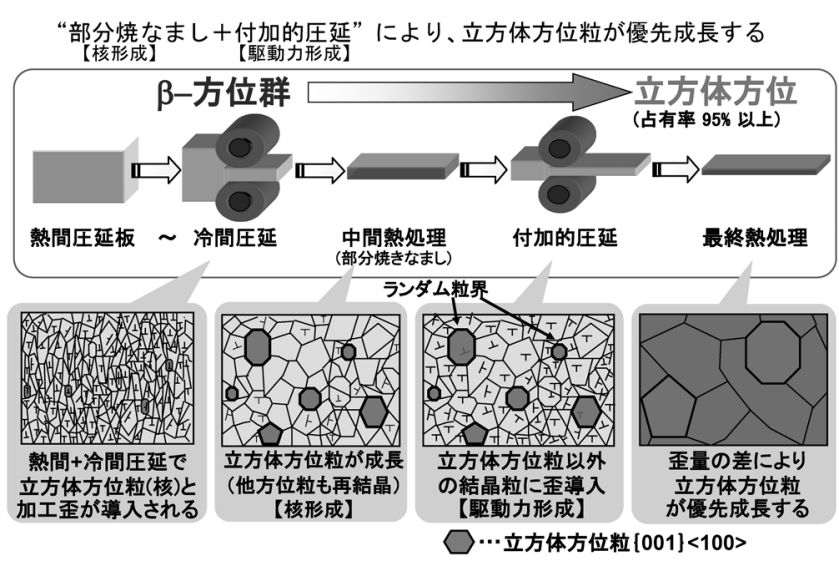

図 20 高圧用箔の結晶方位制御/製造方法の概念図

粒として成長すると考えられる結晶粒（粒W）以外に冷間 圧延集合組織の主方位にも, 細線がほとんどなく再結晶が進 んでいる結晶粒（粒 $\mathrm{B}$, 粒 $\mathrm{C}$, 粒 $\mathrm{S}$ ) が認められる。一方, (b) 付加的圧延材においては, 粒Wには他の方位と比べて細線 が少なく他の主方位よりひずみが蓄積されていないことがわ かる。このことが, 最終熱処理時に立方体方位のみが優先成 長する理由であると考えられている。図20にその概念図を 示す ${ }^{45)}$ 。 


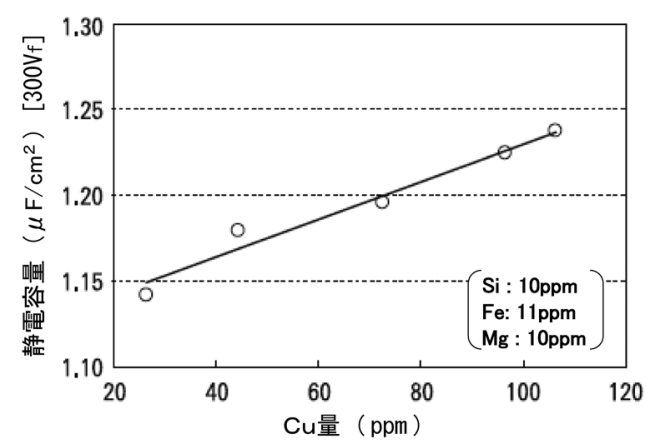

図21静電容量（300Vf）に及ぼす $\mathrm{Cu}$ 量の影響 (䈃厚 : $104 \mu \mathrm{m}$ )
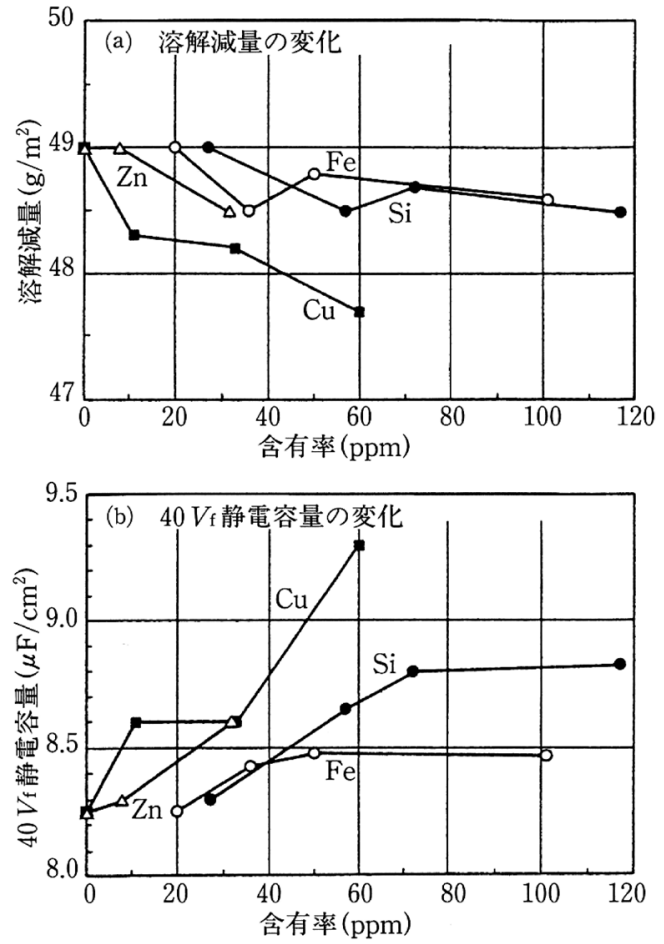

図22 交流エッチング時の溶解減量に及ぼす微量元素 の影響

\section{3 .2 微量元素の影響}

高純度アルミに含有される不純物元素は原料塊とその精製 方法によっても異なるが，その代表的なものは， $\mathrm{Si}, \mathrm{Fe}, \mathrm{Cu}$ である。また精製方法に偏析法を用いた場合には Ga, Ti, V 等 が多くなる傾向にある。

図 21 に高圧用高純度アルミ箔の静電容量に及ぼす $\mathrm{Cu}$ 量の 影響を示す ${ }^{62)}$ 。 $\mathrm{Cu}$ 量の増加とともに静電容量は増加してい る。 $\mathrm{Cu}$ 量については, $30 \mathrm{ppm}$ 付近に最大值を持つとの報告 例もあり ${ }^{63)}$ ，エッチング条件によっては異なる結果となる 可能性が示唆される。

図 22 は, 低圧用高純度アルミ箔について, 塩酸一りん酸 系の浴で交流エッチングした場合の溶解減量と静電容量の 関係に及ぼす微量元素 $\mathrm{Zn}, \mathrm{Cu}, \mathrm{Fe}, \mathrm{Si}$ の影響を示したものであ る ${ }^{12)}$ 。いずれの元素を添加しても溶解減量は減少し, 静電 容量は増加すると言える。特に, $\mathrm{Cu}, \mathrm{Si}$ の添加は静電容量を 増加させる効果が大きい。

図 23 は Fe 量 $0.04 \sim 0.12 \%$ の鋳塊を用いて均質化熱処理条

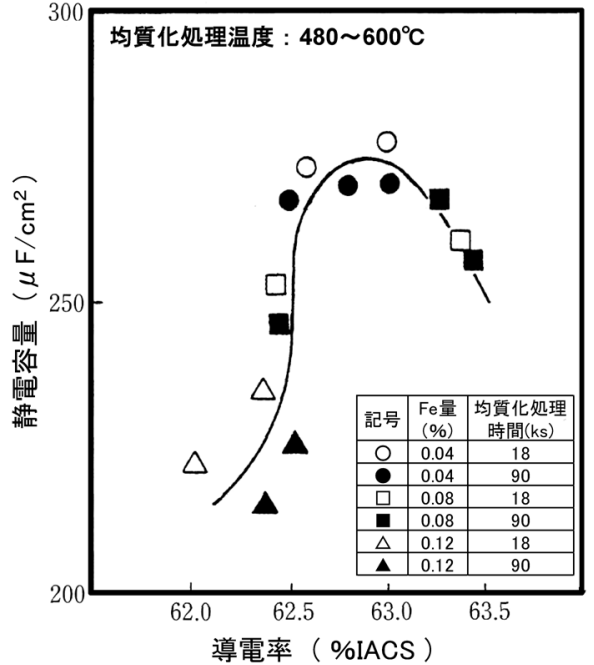

図 23 導電率と静電容量 $(0 \mathrm{Vf})$ との関係 $2.8 \%$ 塩酸 $-7.5 \%$ 塩化アルミ $-0.1 \%$ しう酸水溶 液中で交流エッチング

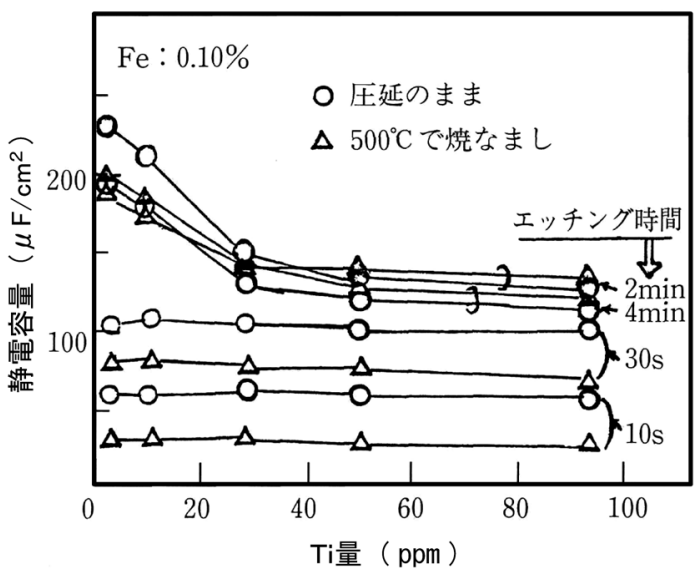

図24院極用箔の静電容量に及ぼすTi含有量および エッチング時間の影響
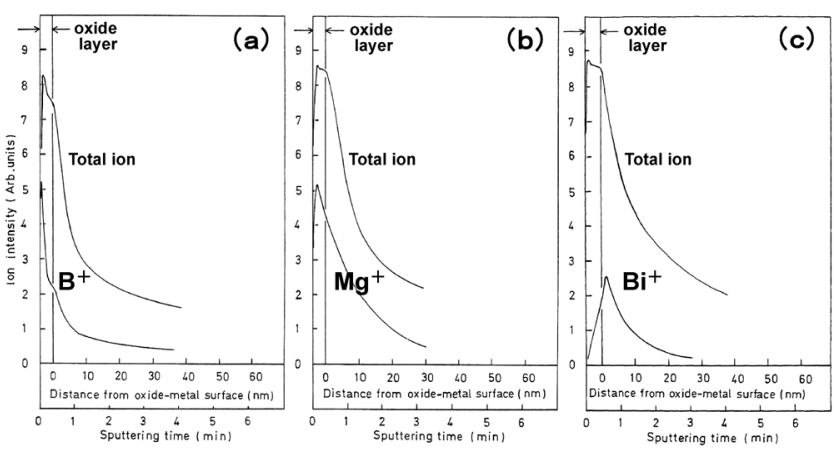

図25高温焼なまし後の $\mathrm{B}, \mathrm{Bi}, \mathrm{Mg}$ の深さ方向の分布 焼なまし条件： $550^{\circ} \mathrm{C}-1 \mathrm{~h}$, 測定方法：SIMS (二次 イオン質量分析法)。(a)，(b) Al-3 ppmB，(c) Al$2 \mathrm{ppmBi}(\mathrm{Mg}$ はいずれも $1 \mathrm{ppm}$ 以下）

件を変え, 最終冷間圧延後の箔の導電率と静電容量特性を評 価したものである。導電率が $62.5 〜 63.0 \%$ IACS のときに静電 容量が極大となる傾向を示している ${ }^{64)}$ 。この導電率の範囲で は, 均質化熱処理時に $\mathrm{Al}-\mathrm{Fe}$ 系の金属間化合物が析出し,これ がエッチングの核となって粗面化が進行したと考えられる。 


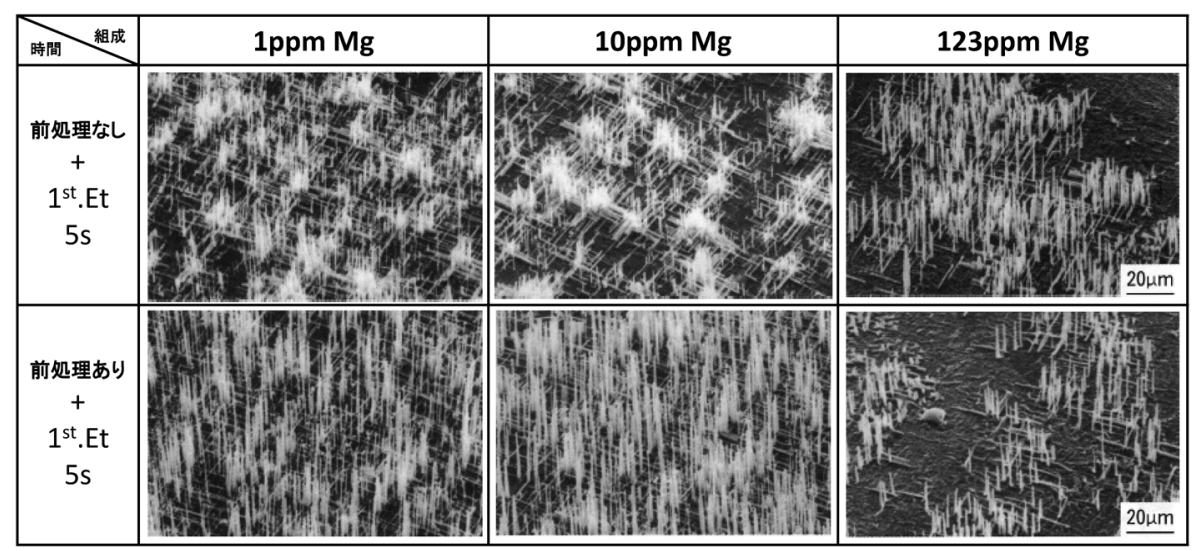

図26エッチング初期 $(5 \mathrm{~s})$ の裏面形態に及ぼす $\mathrm{Mg}$ 量の影響 $8 \mathrm{ppm} \mathrm{Si}-10 \mathrm{ppm} \mathrm{Fe}-50 \mathrm{ppm} \mathrm{Cu}$, 箔厚 : $104 \mu \mathrm{m}$

その他, 低圧箔に含有される微量元素の中でエッチング性 に影響を及ぼす元素としては，7〜 13 ppmの Ti添加で溶解減 量が増加し静電容量が低下する例 ${ }^{65)} や ， 5 \mathrm{ppm}$ のIn添加で エッチピット発生が均一になり, 静電容量が増加する例 ${ }^{66)}$ が報告されている。

図24は陰極用箔の静電容量に及ぼす Ti量の影響を示した ものである。㓌極用箔は非常に薄い酸化膜を形成させるのみ であり, 粗面化の必要性は陽極用箔ほど高くはない。しかし ながら, 陽極側のエッチング容量の向上とともに, 高容量化 のニーズも次第に高まっている。 $30 \mathrm{ppm}$ 以下では, Ti 量の増 加とともにエッチング時間の長い領域での静電容量が低下し ている。また, Tiが $30 \mathrm{ppm}$ 以上含有されるとエッチング時 に全面溶解となり，微細ピットが形成されにくくなる ${ }^{67)}$ 。

\section{3 .3 微量元素の表面濃化}

図 25 にSIMSによる高圧用箔の最終熱処理後の B, Bi, Mg の深さ方向の分布を示す ${ }^{37)}$ 。いずれの元素も表層に濃化し ている点は共通であるものの，（a）B，（b） Mgについては 酸化膜層に濃化し，（c）Biについては酸化膜とアルミの境界 近傍に濃化のピークがあることがわかる。図26はエッチン グ初期暠面形態（樹脂レプリカ：針状の突起がエッチピット

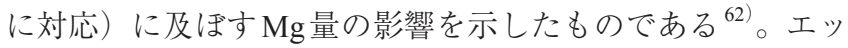
チング前処理なしの場合, $1 \mathrm{ppm} \mathrm{Mg}, 10 \mathrm{ppm} \mathrm{Mg}$ 材ではトン ネルピットが局部集中して発生しているのに対し, エッチン グ前処理ありではエッチピットの局部集中は低減されてい る。これは, 前処理により $\mathrm{Mg}$ の濃化層を含む酸化膜層が除 去され，エッチピットの局部集中が低減されたものと考えら れる。図27は, 静電容量に及ぼす $\mathrm{Pb}$ 量の影響を示したもの であり ${ }^{68)}, \mathrm{Pb}$ 量に適正值が存在することがわかる。図28は, 図27のエッチングの進行過程を断面形態から観察したもの である。図 28 より, $<0.2 \mathrm{ppmPb}$ の材料は, エッチング初期 のエッチピット発生が早いが不均一であり, 終期では局部溶 解（白色 ） が発生している。一方, $1.5 \mathrm{ppmPb}$ の材料はエッ チング初期のエッチピット発生が遅く終期では全面に表面溶 解が起こり, 箔厚が薄くなっている。これが静電容量の低下 に影響を及ぼしたと考えられる。

図29は, 熱処理中での $\mathrm{Pb}$ の挙動を明らかにする目的で, 最終熱処理後の Al-100 ppmPb 材を TEM ステージ内で昇温 し, $\mathrm{Pb}$ 粒子の挙動を連続的に観察したものである（昇温速

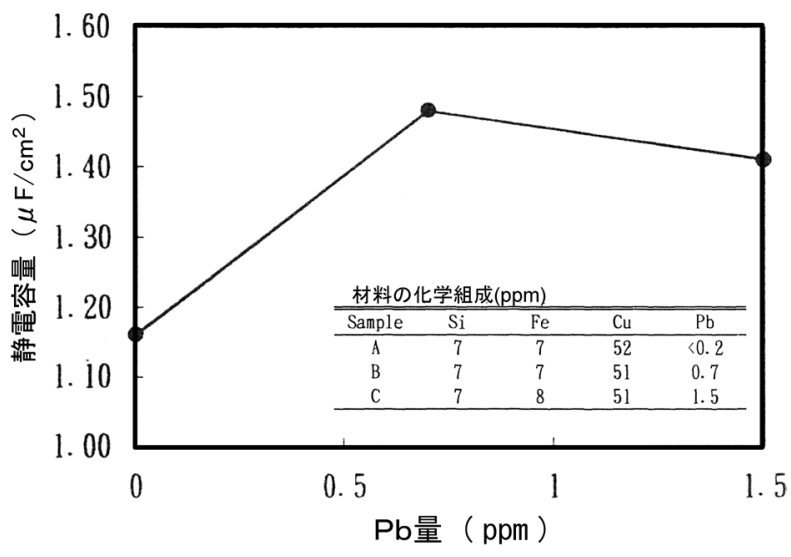

図27静電容量（250Vf）に及ぼす $\mathrm{Pb}$ 量の影響

度 $\left.0.3^{\circ} \mathrm{C} / \mathrm{s}\right)^{69)}$ 。 $320^{\circ} \mathrm{C}$ までは $\mathrm{Pb}$ 粒子はファセット界面を有す る八角形形状を呈しており, その形状を維持している。 $\mathrm{Pb}$ 融点 $\left(328^{\circ} \mathrm{C}\right)$ を超える $335^{\circ} \mathrm{C}$ あたりからァセット界面は 不鮮明になり, $500^{\circ} \mathrm{C} て ゙ \mathrm{~Pb}$ 粒子が消滅している。これは, $\mathrm{Pb}$ がTEM内の高真空中で蒸発したためであると考えられる。 図 29 は Pb量が $100 \mathrm{ppm}$ と図 27 に示される $\mathrm{Pb}$ 適正值より多 い例であるが, $\mathrm{Pb}$ 量が $0.4 \mathrm{ppm}$ と比較的少ない材料において も FE-SEMにより，表層近傍に $\mathrm{Pb}$ と推定される5〜10 nmの 大きさの微粒子の存在が報告されている ${ }^{70)}$ 。また, TEMによ る酸化皮膜中の $\mathrm{Pb}$ 化合物の報告例もある ${ }^{71)}$ 。図30に $\mathrm{Pb}$ の表 面偏析モデルを示す ${ }^{72)}$ 。 $\mathrm{Pb}$ は, アルミ中での拡散, アルミ表面 での酸化と化合物形成, アルミ表面からの蒸発, アルミ中で の再固溶, 等の過程を経て深さ方向の濃度分布を形成するも のと考えられる。微量元素の表面濃化とエッチングについて の報告は, 上記の $\mathrm{B}, \mathrm{Bi}, \mathrm{Mg}, \mathrm{Pb}$ のほかに $\mathrm{Cu}^{62)}, \mathrm{In}^{73)}, \mathrm{Sn}^{73)}$, $\mathrm{Ge}^{74)}, \mathrm{Zn}^{74)}, \mathrm{P}^{74)}, \mathrm{Ca}^{75)}, \mathrm{Sr}^{75)}$ 等についての報告例がある。

実生産のアルミ電解コンデンサ用箔について, GD-MSに よる各微量元素の深さ方向の濃度分布を測定し, 最大偏析濃 度を箔原料濃度で除した值を表面偏析度として偏析位置とと もに表4に示す ${ }^{39)}$ 。表4より, アルミ箔表面での表面偏析は 各元素で大きく異なり, 最大偏析位置についても一様ではな い。この原因については, 各元素の融点, 蒸気圧, アルミ中 での固溶限, アルミとの化合物の作りやすさ, 酸化のされや 


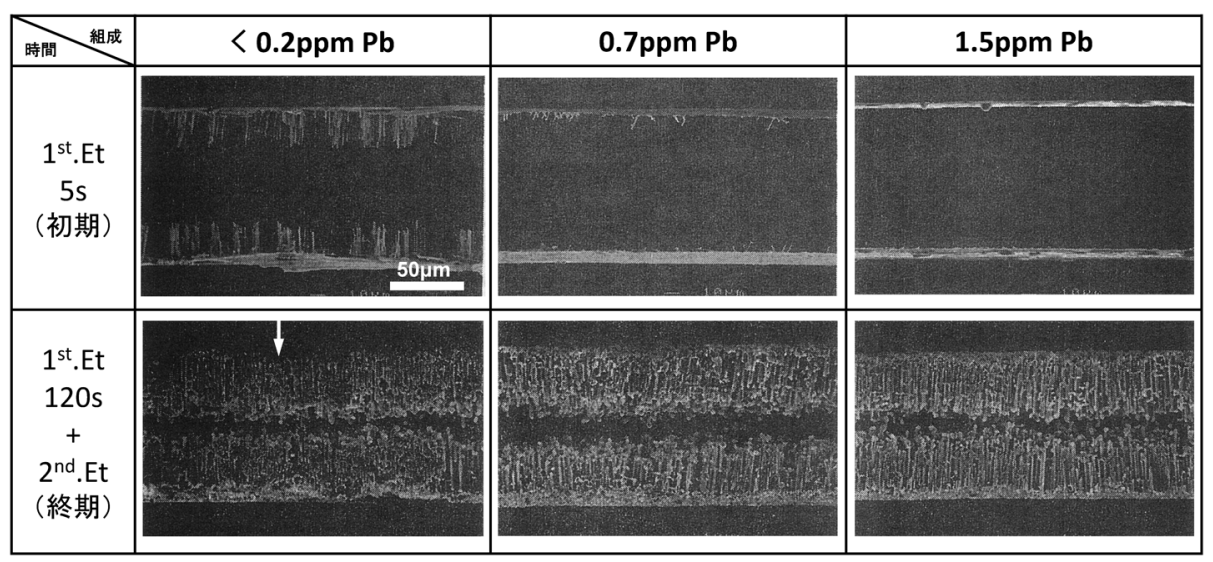

図28 エッチング断面形態に及ぼす $\mathrm{Pb}$ 量の影響（箔厚：110 $\mu \mathrm{m}$ ）

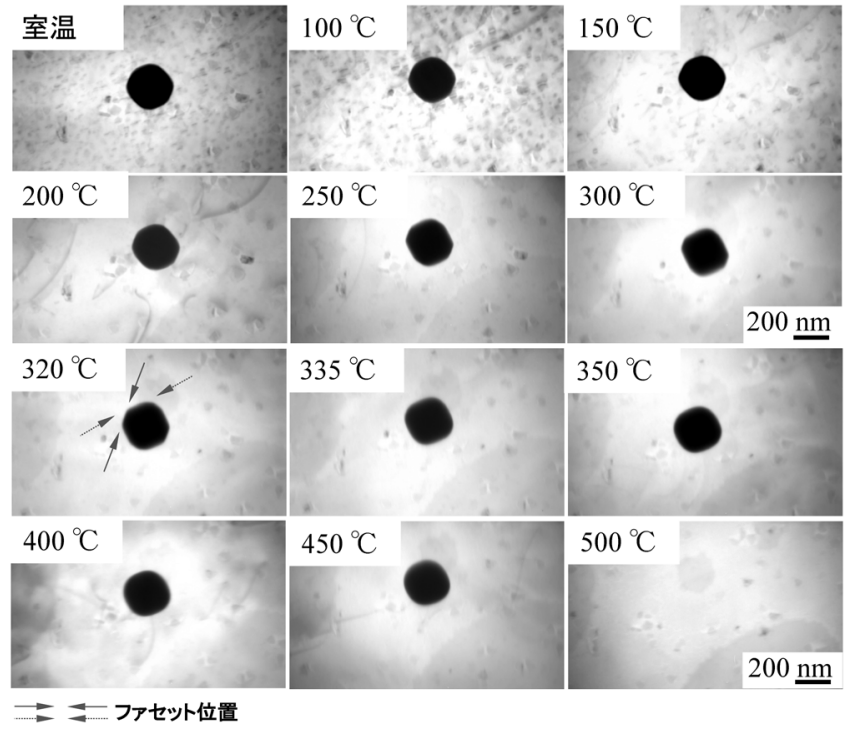

図 $29 \mathrm{Al}-100 \mathrm{ppmPb}$ を TEM ステージ内で昇温した場合 の $\mathrm{Pb}$ 粒子の挙動

【焼鈍初期】

\section{【後期】}

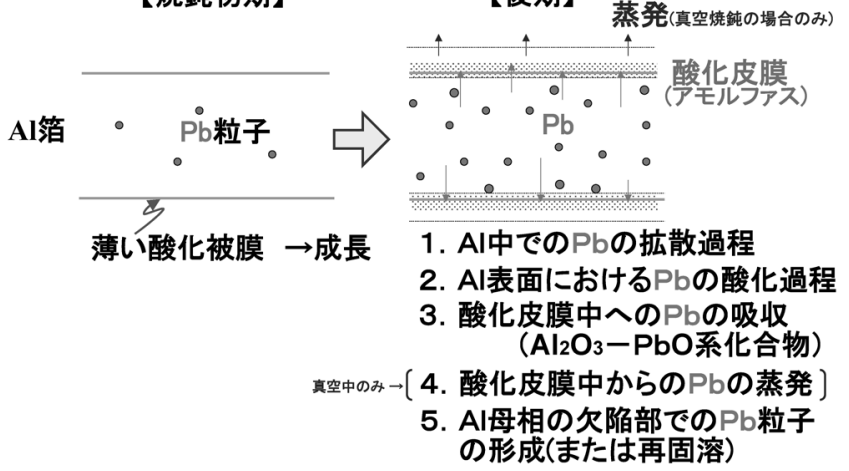

図30 アルミニウム中における $\mathrm{Pb}$ の表面偏析モデル

すさといった要因が影響していることが考えられる。

\section{3 .4 ひずみの影響}

図 31 は, 焼なまし後の箔に引張ひずみを与えた後, 直流 エッチング処理し, その筞の樹脂レプリカ像を観察した結果 である ${ }^{76)}$ 。わずかな引張ひずみは初期のエッチピットを伸長 させるが,ささらに引張ひずみを与えるとエッチピットの発生
表4 各種元素の表面偏析度 (GDMS)

\begin{tabular}{l|r|c|c}
\hline \hline 元素名 & 表面偏析度 & $\begin{array}{c}\text { 最大偏析濃度 } \\
(\mathrm{ppm}) / \text { 箔原料濃 } \\
\text { 度 }(\mathrm{ppm})\end{array}$ & $\begin{array}{c}\text { 箔表面からの偏 } \\
\text { 析位置 [最表層 } \\
\rightarrow \text { 内層側 }\end{array}$ \\
\hline $\mathrm{B}$ & 7000 & $2100 / 0.3$ & $10 \mathrm{~nm}$ 近傍 \\
$\mathrm{Mg}$ & 6000 & $1800 / 0.3$ & $25 \mathrm{~nm}$ 近傍 \\
$\mathrm{Si}$ & 73 & $1100 / 15$ & $40 \mathrm{~nm}$ 近傍 \\
$\mathrm{Ti}$ & 269 & $350 / 1.3$ & 最表層 \\
$\mathrm{Mn}$ & 182 & $1200 / 6.6$ & $10 \mathrm{~nm}$ 近傍 \\
$\mathrm{Fe}$ & 1000 & $11000 / 11$ & $10 \mathrm{~nm}$ 近傍 \\
$\mathrm{Ni}$ & 6750 & $2700 / 0.4$ & 最表層 \\
$\mathrm{Cu}$ & 350 & $17500 / 50$ & 最表層 \\
$\mathrm{Zn}$ & 37 & $350 / 9.4$ & 最表層 \\
$\mathrm{Ga}$ & 3 & $40 / 12$ & $20 \mathrm{~nm}$ 近傍 \\
$\mathrm{Zr}$ & 60 & $600 / 10$ & 最表層 \\
$\mathrm{Sn}$ & $>7000$ & $700 /<0.1$ & $30 \mathrm{~nm}$ 近傍 \\
$\mathrm{Pb}$ & 3200 & $1600 / 0.5$ & $50 \mathrm{~nm}$ 近傍 \\
$\mathrm{La}$ & 800 & $1200 / 1.5$ & $10 \mathrm{~nm}$ 近傍 \\
$\mathrm{Ce}$ & 2200 & $5500 / 2.5$ & $10 \mathrm{~nm}$ 近傍 \\
$\mathrm{Pr}$ & 1000 & $200 / 0.2$ & $10 \mathrm{~nm}$ 近傍 \\
$\mathrm{Nd}$ & 1700 & $1500 / 0.9$ & $10 \mathrm{~nm}$ 近傍 \\
\hline
\end{tabular}

が不均一になることがわかる。図 32 は, 引張ひずみを与え た箔の 5 秒間初期エッチング後の静電容量である。静電容量 は引張ひずみ量に対してピークを持っている ${ }^{76)}$ 。ひずみの影 響については, 最終熱処理後の箔に 10〜20\%軽圧下圧延に よりエッチング後のピット密度が上昇するとの報告 ${ }^{77)} も あ ~$ り, 加工により導入された表面の皮膜の欠陥あるいは転位の 分布がエッチングに影響を及ぼしていることが示唆される。

図33は，箔の表面近傍のミクロ結晶組織（転位組織）を 模式図で示したものである ${ }^{77)}$ 。箔表層には圧延筋（圧延ロー ルにより形成された筋状の凹凸）に沿って転位密度の高い領 域，酸化物粒子が存在し，そのすぐ直下には転位密度の高い 微細なサブグレインが存在すると推定されている。図34は 箔表層を非常に浅い角度で斜めにスライスした面の channeling BSE像である。圧延筋が見える左側が削り取られていな い圧延表面, 中央部から右側が䇴内面に向かって切断された 面である。図34からも, 箔表層の圧延筋直下には微細なサ 


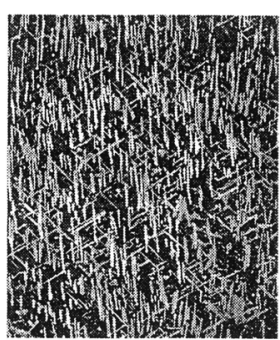

$0 \%$

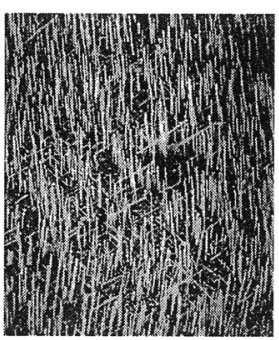

$0.3 \%$

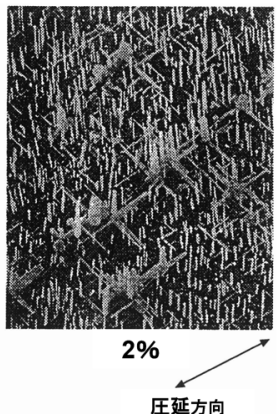

圧延方向
図 31 引張ひずみを与えた箔の 5 秒間エッチング後の ピットの裏面形態（引張方向は圧延方向に平行） $9 \mathrm{ppm} \mathrm{Si}-10 \mathrm{ppmFe}-45 \mathrm{ppm} \mathrm{Cu}$, 䇴厚 : $104 \mu \mathrm{m}$

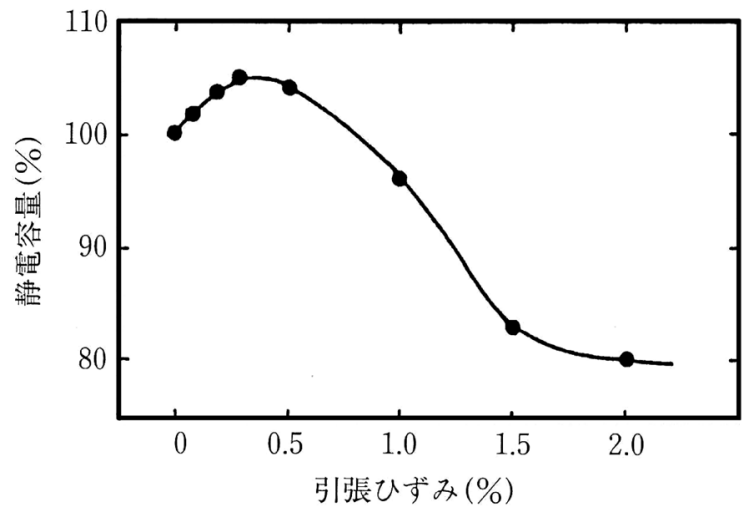

図 32 引張ひずみと直流エッチング後の静電容量 (350Vf) との関係

静電容量は,ひずみを与えない場合の静電容量を $100 \%$ として相対值を示した

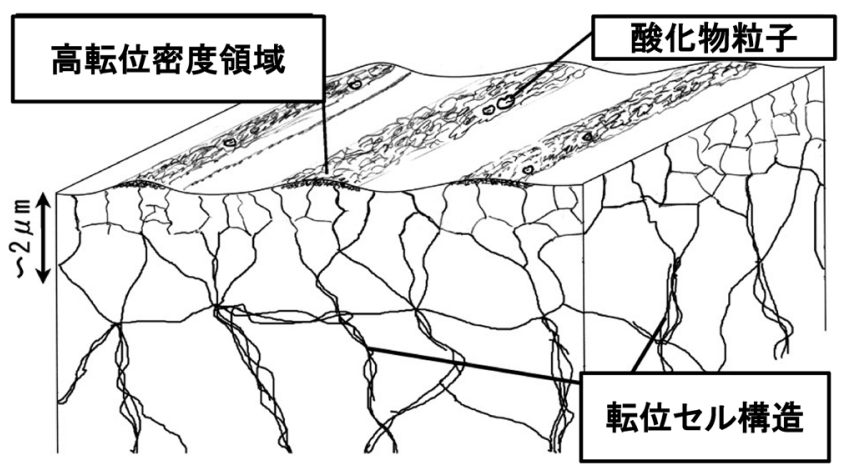

図33最終熱処理後の表面近傍の微細組織の模式図

\section{ブグレイン組織が存在することが示唆されている ${ }^{78)}$ 。}

\section{3 .5 酸化膜の影響}

図35は，最終焼なまし前に大気中で酸化処理を施した後, 焼なましした試料について直流エッチング処理時間を変え た場合の静電容量の変化を示したものである ${ }^{79)}$ 。図 35 から, 焼なまし前の酸化処理時間には適正值が存在していると言え る。また, 最終熱処理前の洗浄条件の違いにより, 最終熱処 理後の酸化皮膜特性や塩酸浴中での表面反応性が変化すると の報告もあり ${ }^{80)}$ ，酸化膜は，エッチングに対する重要な要 因の一つであると言える。

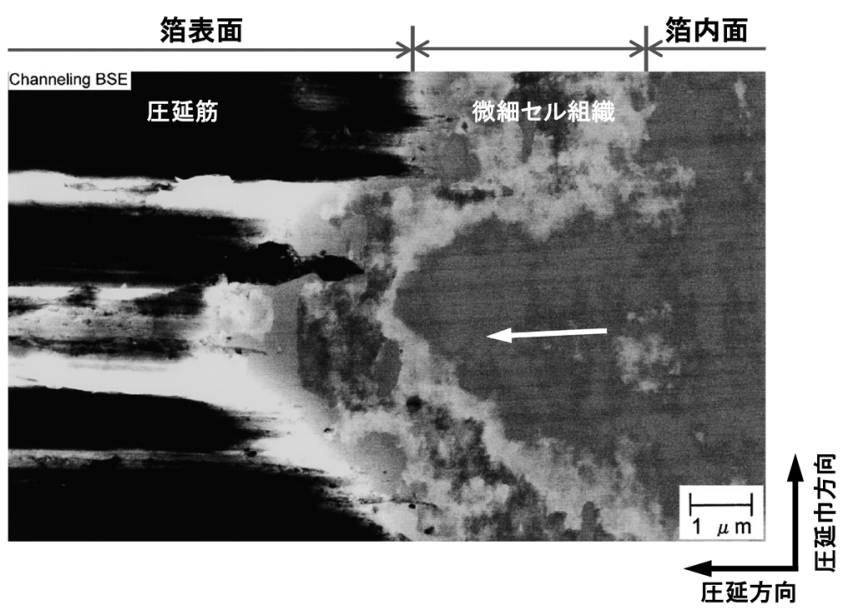

図34 高圧電解コンデンサ用アルミ箔表面組織の channeling BSE像

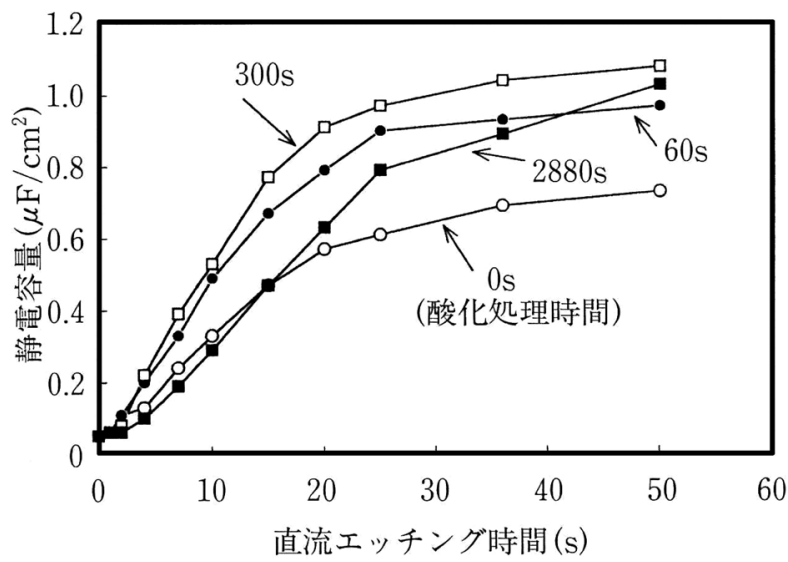

図35最終焼なまし前の大気中酸化処理時間を変えた ときの静電容量 $(300 \mathrm{Vf})$ の電解時間による変化 5 ppmSi-9 ppmFe- 36 ppmCu, 箔厚 : $100 \mu \mathrm{m}$

\section{6. おわりに}

本稿では，アルミ電解コンデンサの歴史，それに使われる 高純度アルミ箔に要求される特性とそれを満足するために必 要な要因について触れてきたが, 全体を通して以下のことが 言える。

（1） アルミ電解コンデンサは, 非常にシンプルな構造, 基本原理である。製品や要求特性が変化しても基本的に要求 されるものは同じであり，この点が今も強みとなっている。

（2）アルミ電解コンデンサは, 代替品の脅威にさらされ ながらも，自己修復機能を持ち広範囲な定格電圧に対応可能 な誘電体皮膜と, アルミ箔のコイルエッチング〜化成処理に よる小型化が可能であるという特徴を活かし, 現在も特に電 源回路用途を中心に高定格電圧ならびに高静電容量の領域に おいて成長を続けている。

今後も車載用途, 風力・太陽光発電用途をはじめ, 通信 · エネルギー・産業機器分野での需要拡大が見达まれるが, フィルムコンデンサやセラミックコンデンサとの差別化を図 るためにはさらなる高静電容量化が要求される。

（3）アルミ箔表面の酸化膜特性, 結晶組織, 微量元素の 濃度とその分布等の解析技術が進化するに従い，今まで解明 
されていなかった材料の状態やエッチングとの関係が次第に 明らかになってきた。これらすべての解析技術がアルミ電解 コンデンサ用箔の開発に必須であったとは言えない。しかし ながら，(1)なぜ特性がよくなったかを理解し，(2)安定生産に 繋げるとともに，(3)次の開発のヒントをつかむ，ことは製品 の継続的発展のために不可欠のステップであると言える。製 品は解析技術の発展とともに進化する。

（4）世の中の多様なニーズとその変化に合せて，アルミ 電解コンデンサも小型, 長寿命, 高定格電圧, 低ESR, 耐リッ プル，耐熱用途等への適合化を図ってきた。今後、アルミ電 解コンデンサがさらに発展するためには，新たな技術革新が 必要であり，高純度アルミ箔にもそれに呼応する特性改善が 要求される。

\section{参 考 文 献}

1) キャパシタ便覧：丸善出版, (2009)，3-6

2) 新井浩三，鈴木崇生：軽金属，31（1981），675-682.

3) 山口謙四朗：軽金属，35（1985），365-371

4) 永田伊佐也：軽金属, 38 (1988), 552-557.

5) 佃 市三：第49回シンポジウムテキスト, 軽金属学会, (1996), 20-25

6) 小菅張弓：軽金属, 38 (1988), 238-248.

7) 麻草春海, 佐藤朋有, 高橋明彦, 前田秀雄：住友化学, 1988II, (1998), 69-86

8) 永田伊佐也：電解液院極アルミニウム電解コンデンサ，日本蓄 電器工業, (1997), 574.

9）永田伊佐也：電解液陰極アルミニウム電解コンデンサ, 日本蓄 電器工業, (1997), 169-172, 338.

10) C. G. Dunn, R. B. Bolon, A. S. Alwan and A. W. Stirling: J. Electrochem. Technol., 118 (1971), 381-390.

11）神崎信義：アルミニウム, 2 (1995)， 130-140.

12）福岡 潔, 倉橋正晴：住友軽金属技報, 28（1987），7-14

13）神崎信義, 島谷涼一, 高橋 寛, 徳外弘幸 : 表面技術, 41 (1990), $14-18$.

14）清水健一，小林賢三， G. E. Thompson and G. C. Wood：金属表 面技術，35（1984），374-382.

15) 永田伊佐也：電解液陰極アルミ電解コンデンサ, 日本蓄電器工 業, (1997)，31-33.

16）電子情報技術産業協会，2022年までの電子部品技術ロードマッ プ. (2013), 111

17）小菅張弓：軽金属学会第87回秋期大会講演概要，(1994）, 275278.

18） 三久保滋：アルミニウム，4 (1997)，438-445.

19）星河浩介, 田中一郎, 恵 智裕：住友化学, 2013 (2013), 10-19.

20）渡辺修一郎：金属, 58, No. 1 （1988），8-13

21）土橋倫男：軽金属, 44（1994），406-417.

22) アルコア：特許公告, 昭49-5806.

23）カンパニー・ペシネー：特許公告，昭 50-20536。

24) 日本軽金属：日本特許, 1427312 (1987).

25）昭和アルミニウム：日本特許, 1601231（1990）

26) 住友化学：日本特許, 3370689 (2002).

27) 三菱軽金属工業：日本特許, 1577731（1990）。

28）軽金属学会編：アルミニウムの製品と製造技術，（2001）， 107

29) 日本アルミニウム協会資料.

30) 日本アルミニウム協会：2014年度「アルミニウム」圧延品需要 見通し，(2014）。

31）産業情報調査会：2013年版コンデンサ市場, （2013）, 131 .

32）田内達治：電解蓄電器評論， 56-1（2005），105-128

33) 中野 稔: 電解蓄電器評論, 58-2 (2008), 110-120

34) 田中一郎：電解蓄電器研究会特別講演資料, (2013-5)

35)内 秀則：第 30 回ARS 弘前コンファレンス, (2013), 17-26.

36) 神崎信義：電解蓄電器評論, 58-2 (2008), 75-109.

37) K. Arai, T. Suzuki and T. Atsumi: J. Electrochem. Soc., 132 (1985), 1667-1671

38) Z. Ashitaka, G. E. Thompson, P. Skeldon, G. C. Wood and K.
Shimizu: J. Electrochem. Soc., 146 (1999), 1380-1385.

39) 田中真一：電解蓄電器評論, 61-1 (2010), 107-114

40) 清水健一：表面技術，59（2008），904-906.

41) 村上 雄, グエン・コン・ダン, 高橋恒夫：軽金属, 28(1978), 267-271.

42）新井浩三，鈴木崇生：軽金属, 31（1981），334-340.

43）遠藤誠一，稲垣裕輔：軽金属, 52（2002）, 167-173.

44) 小林保夫, 三笠 和：軽金属学会第 65 回秋期大会講演概要, (1983), 53-54.

45) 池田賢一, 津曲兼一郎, 吉田冬樹, 中島英治, 阿部 弘：軽金 属, 51 (2001), 119-124.

46) M. S. Hunter and P. Fowle: J. Electrochem. Soc., 103 (1956), 482485.

47）大脇武史：神戸製鋼技報， 50-2（2000），70-73.

48）日比野敦, 興戸正純, 沖 猛雄：軽金属, 44（1994）, 298-304.

49) R. S. Alwitt, H. Uchi, T. R. Beck and R. C. Alkire: J. Electrochem. Soc., 131 (1984), 13-17.

50) 牧野英司, 矢島宇生, 菅沼榮一：精密工学会誌, 55（1989）, 1633-1638.

51）日比野敦, 玉置充宏, 渡辺吉章, 沖 猛雄 : 軽金属, 42（1992）, 440-445.

52）小浦延幸, 松本 太, 猿渡秀郷, 北原しのぶ, 山崎 崇, 井手 本康, 古川雅一, 内 秀則：表面技術, 53 (2002), 612-617.

53) 菅沼栄一, 丹野裕司, 伊藤 武, 船越 明, 松本健三 : 表面技 術, 41 (1990)， 1049-1053.

54) 片野雅彦: 軽金属学会第80回春期大会講演概要, (1991), 117-118.

55) 山ノ井智明：第50回シンポジウムテキスト, 軽金属学会, (1996), 62-69.

56) 山本兼滋, 荒木啓一：軽金属学会第 83 回秋期大会講演概要, (1992), 75-76.

57) カンパニー・ペシネー：特許公告, 昭 54-11242.

58）牧野英司, 竹田浩治, 矢島宇生, 佐藤敏一, 菅沼栄一：金属表 面技術，39（1988），446-451。

59）上条太一, 関 史江, 玉井宏規, 伊藤邦夫：軽金属, 49（1999） 589

60）岡田 浩，土屋清美，小菅張弓，清水 遵：軽金属学会第 96 回春期大会講演概要, (1999), 309-310.

61） 福岡 潔, 大沢伸夫：住友軽金属技報，35（1994），90-96.

62）日比野敦, 大澤伸夫, 竹井邦夫：住友軽金属技報, 44（2003）, 19-27.

63）川島波夫，中村雄造，西坂 基：軽金属，21（1956），54-59，

64) 山本兼滋，荒木啓一：軽金属学会第79回秋期大会講演概要, (1990)，53-54.

65）福岡 潔，佐々木茂明，倉橋正晴：住友軽金属技報，36（1995）, $127-132$.

66）福岡 潔，倉橋正晴：住友軽金属技報，34（1993），7-14.

67) 松井邦昭：軽金属学会第72回春期大会講演概要, (1990), 181-182.

68) 名取敏雄, 細田昌孝, 石田由美子：電解蓄電器評論, 47-2 (1997), 48-55.

69）野上敦司，椿野晴繁，寺澤倫孝，三田村徹，山ノ井智明，木野 村敦, 堀野裕治：軽金属, 53 (2003)，195-199

70) 清水健一, 三谷智明, 幅崎浩樹：工業材料, 55 (2007), 90-95.

71) 川井正彦，清水健一：表面技術協会第 102 回講演大会要旨集, (2000), 94.

72）椿野晴繁，野上敦司，寺澤倫孝三田村徹，山ノ井智明，木野 村敦, 堀野裕治：軽金属, 52 (2002)，410-416。

73） 大澤伸夫，日比野敦：住友軽金属技報，44（2003），12-18.

74) 伊藤麻美, 片野雅彦：電解蓄電器評論, 62-1 (2011), 101-106.

75) 山ノ井智明：電解蓄電器評論, 64-1 (2013), 119-130.

76）福岡 潔，大澤伸夫：住友軽金属技報，36（1995），133-139。

77) 川井正彦, 山田和広, 梅崎智典, 小西 章, 渡辺英雄, 美浦康 弘：軽金属, 54 (2004)，211-217.

78）清水健一：軽金属，56（2006）, 454-458.

79）多田清志, 粟屋庫太 : 軽金属, 50（2000）, 590-593.

80) 櫻井 強, 星野晃三, 佐藤文博：神戸製鋼技報, 48（1998）, 9-12. 